REVISTA DE DERECHO UNED, NÚM. 21, 2017

\title{
LA NECESARIA REFORMA DE LA MAL LLAMADA «JURA DE CUENTAS»
}

\author{
THE NECESSARY REFORM OF THE BAD CALL \\ "OATH OF ACCOUNTS"
}

\author{
Premio de Artículos Jurídicos García Goyena \\ XVI Edición \\ Primer accésit
}

José BONET NAVARRO

Resumen: Con ocasión de las cuestiones prejudiciales formuladas ante el Tribunal de Justicia de la Unión Europea sobre el control de cláusulas abusivas en el llamado «expediente de jura de cuentas», la Abogada General concluye que la regulación del procedimiento es inadecuada conforme al derecho de la Unión. Indirectamente, pone también en evidencia graves defectos en la regulación, principalmente porque se invaden funciones que corresponden exclusivamente a la jurisdicción. En la reforma procesal que seguirá en el caso de que la Sentencia del Tribunal de Justicia de la Unión Europea, y también en la reforma que debería seguirse en caso contrario, deberá garantizarse el control de oficio y suficiente de las cláusulas abusivas por el titular de la potestad jurisdiccional.

Palabras clave: Abogado, procurador, reforma procesal, jura de cuentas, cláusulas abusivas.

Abstract: On the occasion of the preliminary rulings exercised before the Court of Justice of the European Union on examination ex officio of possible unfair terms in the expedient called «manifestation of accounts», the General Counsel concludes that the procedure is inappropriate according to the law of the Union. Indirectly, it reveals serious defects in regulation, mainly because it invades exclusive domains of the jurisdiction. In the procedural reform that will continue in 
the event that the Sentence of the Court of Justice of the European Union, and also in the reform that should be followed otherwise, the ex officio control of the abusive clauses by the judge must be guaranteed.

Key words: Lawyer, procurator, procedural reform, «manifestation of accounts», unfair terms.

Sumario: I. Aproximación sintética al mal llamado "expediente de jura de cuentas». II. De la «jura» a la «manifestación» de cuentas, una travesía para superar ciertas dudas de constitucionalidad. III. El retorno de la polémica, el señorío absoluto del «Secretario Judicial» a partir de la Ley 13/2009. IV. Una oportunidad perdida, el reforzamiento del poder del Letrado-Secretario en la reforma operada por la Ley 42/2015, de 5 de octubre. V. De fuera vendrán y nos advertirán, la inadecuación al derecho de la unión y la necesaria reforma. VI. Consideraciones complementarias para «macizar» el carácter jurisdiccional de la «manifestación de cuentas». VII. A modo de conclusión, la reforma procesal que viene: 1 . La propuesta de la abogada general es coherente y parece derivar de la misma que el control de "abusividad» debe residir en el «Secretario Judicial». 2. El control del las cláusulas abusivas por el titular de la potestad jurisdiccional: A) La vuelta a la situación anterior a la Ley 13/2009. B) Mantenimiento de la intervención del "Letrado de la Administración de Justicia» de modo similar a lo previsto en el artículo 815.4 LEC. C) Derogación del procedimiento, introduciendo, en su caso, especialidades. 3. Las posibilidades probatorias en el control de las cláusulas abusivas y los procesos sumarios.

Este trabajo focaliza su atención en un aspecto de la necesaria separación de poderes según el modelo constitucional y, más en concreto, en la integridad del espacio que corresponde a la jurisdicción. No se encuentran en su punto de mira los intereses corporativos de los llamados «Letrados de la Administración de Justicia» o «Secretarios Judiciales» ${ }^{1}$, a pesar de que, por alguna ignota razón, una de sus aspiraciones parece que es la de poder «juzgar», en contra de lo que establece el artículo 117.3 de la Constitución española.

${ }^{1}$ La LO 7/2015, de 21 de julio, de modificación de la Ley Orgánica del Poder Judicial, en vigor desde el 1 de octubre de 2015, efectivamente denomina como «Letrados de la Administración de Justicia» a quienes, cinco días más tarde, la Ley 42/2015, de 5 de octubre, de reforma de la Ley de Enjuiciamiento Civil, vuelve a denominarlos «Secretarios Judiciales», justamente en setenta y tres ocasiones (cinco en el preámbulo, cincuenta y ocho entre sus preceptos, y diez en las disposiciones transitorias y finales). Aunque la posterior no es orgánica, también es cierto que el cambio de denominación no parece que requiera tal rango legislativo. Lo bien cierto es que, por tal motivo, en este trabajo se aludirá al citado cuerpo profesional con las dos denominaciones indistintamente, y hasta incluso como «Secretario-Letrado». 
Lo bien cierto es que, en general, puede observarse una marcada tendencia a horadar o limar el ámbito de ejercicio de la potestad desde diversos frentes ${ }^{2}$ : sea incentivando artificialmente vías alternativas, sea atribuyendo a órganos administrativos competencias parajudiciales, o sea trasladando funciones judiciales a profesionales que, por muy cualificados que sean, carecen de potestad jurisdiccional. Nótese en esta línea como últimamente la Ley 15/2015, de 2 de julio, de la Jurisdicción Voluntaria, en su Disposición final undécima, introduce los artículos 70 y 71 de la Ley de 28 de mayo de 1862, del Notariado, que regula un procedimiento para «la reclamación de deudas dinerarias no contradichas» por Notario, que es un equivalente extrajudicial del proceso monitorio ${ }^{3}$. Y ya antes, la Ley 13/2009, entre otras muchas cosas, había ya apoderado exclusivamente al «Secretario Judicial» para conocer del procedimiento para que abogados y procuradores puedan reclamar créditos frente a sus clientes en los términos de los artículos 34 y 35 LEC, sin que en este caso, y a diferencia de lo que ocurre en el proceso monitorio, pueda afirmarse que este funcionario actúe por delegación o colaboración con el juez.

Esto último ha recuperado actualidad como consecuencia de las conclusiones que la abogada general, Dña. Juliane Kokott, formuló el 15 de septiembre de 2016 con ocasión de las cuestiones prejudiciales que elevó el Letrado de la Administración de Justicia del Juzgado de Violencia sobre la Mujer núm. 1 (único) de Terrassa (Barcelona). Estas cuestiones derivan de un procedimiento de reclamación de honorarios de un abogado frente a su cliente, en el que se cuestiona su conformidad con el derecho de la Unión por la imprevisión sobre el control de oficio de las cláusulas abusivas en los contratos con consumidores. Pues bien, aunque se formulen con ocasión de la legitimación del «Secretario Judicial» para formular las cuestiones prejudiciales, las conclusiones derivan del análisis de la actividad y el papel que juega el «Secretario Judicial» hasta el punto que lo considera como «órgano jurisdiccional» a los efectos del derecho la Unión. De ese modo, aunque sea indirectamente, permite visualizar que este funcionario podría estar ejerciendo una actividad que requiere una potestad jurisdiccional de la que carece.

${ }^{2}$ Herrero Perezagua, J. F., Lo jurisdiccional en entredicho, Thomson Reuters Aranzadi, Cizur Menor, 2014, pág. 25, menciona como filtros «desde la potenciación de los llamados medios alternativos... a la desjudicialización de algunos mecanismos hasta ahora atribuidos a los tribunales, pasando por el encarecimiento del acceso al proceso y la limitación de las vías de impugnación».

${ }^{3}$ Véase Bonet NaVARRo, J., "Reclamación de deudas no contradichas a través de notario (un instrumento entre la deficiencia y la eficacia)», en Revista Ceflegal, CEF, núm. 190, noviembre de 2016, págs. 1-38. 
En la reforma procesal que procederá en el caso de que, por último, la Sentencia del Tribunal de Justicia de la Unión Europea recoja estas conclusiones, y hasta incluso a pesar de que tan previsible acontecimiento no se produzca dado el estado de la cuestión que evidencia, requerirá sin duda que se garantice el debido control de oficio de las cláusulas abusivas. Pero además será necesario también el respecto del marco constitucional y la integridad del ámbito de ejercicio de la jurisdicción.

\section{APROXIMACIÓN SINTÉTICA AL MAL LLAMADO «EXPEDIENTE DE JURA DE CUENTAS»}

Común pero infundadamente se denomina como «jura de cuentas» al procedimiento que en la actualidad, desde la Ley de Enjuiciamiento Civil 1/2000 (LEC), debería denominarse como «manifestación de cuentas» o expresión similar, en la medida que se sustituye la exigencia de que la cuenta «se jure» por una manifestación más o menos formal de que el crédito es debido, existe, está vencido y es exigible, según los artículos 34 y 35 LEC.

Mediante este procedimiento especial, que instrumenta la técnica monitoria debidamente adaptada, el abogado o procurador solicita al «Secretario Judicial» que requiera al representado o defendido en un determinado proceso para que pague totalmente o formule oposición, con la advertencia de que, en caso contrario, se despachará ejecución. Si el deudor paga totalmente terminará el proceso; si se formula oposición, se transforma formalmente en el procedimiento previsto para la impugnación de la cuenta o la minuta; y si no se cumple el requerimiento o se paga parcialmente, finaliza y, previa solicitud, podrá abrirse la ejecución ${ }^{4}$.

Su vocación es la rapidez, otra cosa es que la misma se logre. Y se prevé para una determinada y muy concreta pretensión, como es la de dar una cierta cantidad de dinero debida por los derechos y gastos que hubiere suplido para el asunto, o por los honorarios que hubieren devengado en el asunto, documentada en la cuenta detallada y justificada, o minuta detallada con manifestación formal de que le son debidos ${ }^{5}$.

\footnotetext{
${ }^{4}$ Por eso en este trabajo se denominará indistintamente como procedimiento o expediente de «jura de cuentas», así como también de «manifestación de cuentas», de «cuenta manifestada» o expresión equivalente.

${ }^{5}$ Véase, entre otros, Mascarell Navarro, M. ${ }^{\mathrm{a}}$ J., "Jura de cuentas y fraude procesal», en Revista Justicia, núm. IV, 1982, págs. 138-44. MarTínez MEGías, R., y RodríGuez Monteys, J. M. ${ }^{\mathrm{a}}$, La jura de cuentas. Honorarios profesionales de abogados y procuradores. Análisis doctrinal y jurisprudencial de los arts. 7, 8 y 12 de la Ley de Enjuiciamiento Civil, Atelier procesal, Barcelona, 1998. Herrero Perezagua, J. F., «Arts.
} 
Este procedimiento destaca, al menos por lo que ahora nos interesa, por las siguientes características sintéticamente enunciadas: la tutela del crédito se fortalece incluso en comparación con las alternativas procedimentales como el monitorio; conocerá el «Secretario judicial» que integre el órgano en que radique el asunto; el documento creado unilateralmente se presume que constituye principio de prueba con la mera manifestación formal de que las cantidades son debidas y no satisfechas; el plazo que se otorga en el requerimiento es solamente de diez días; se configura como proceso sumario por la limitación de los medios de prueba ${ }^{6}$; si hay impugnación, se tramitará diversamente en función de que se base en ser los créditos indebidos o excesivos, y la cantidad debida se determinará mediante decreto irrecurrible aunque, como no puede ser de otro modo, no está dotado de eficacia de cosa juzgada; y, por último, si el requerido mantiene una actitud pasiva, se podrá despachar una ejecución que se seguirá, aunque no se precisa, como si de una sentencia se tratase ${ }^{7}$.

\section{DE LA «JURA» A LA «MANIFESTACIÓN» DE CUENTAS, UNA TRAVESÍA PARA SUPERAR CIERTAS DUDAS DE CONSTITUCIONALIDAD}

Con precedente en las Ordenanzas de las Audiencias, se reguló por primera vez en la Ley de Enjuiciamiento Civil de 1881 (artículos 8 y 12 de la misma) un procedimiento especial para que los procuradores y abogados pudieran reclamar eficientemente a sus representados

34 y 35», en Comentarios a la Ley de Enjuiciamiento Civil, I (coor.: Cordón, Muerza, Armenta y TAPIA), Aranzadi, Elcano, 2001, págs. 378-92. CedeÑo Hernán, M., Retribución de Abogados y Procuradores: la llamada «Jura de Cuentas», Aranzadi, Elcano, 2002. Moreno Catena, V., y Arnaiz Serrano, A., "La intervención y designación del abogado y los procesos de jura de cuentas (arts. 31 a 35 a la Ley de Enjuiciamiento Civil», en Indret, Revista para el Análisis del Derecho, 1/2006, http://www.indret.com, págs. 1-37. ACHÓN BRUÑEN, M. ${ }^{a}$ J., "Los procedimientos de reclamación de la cuenta del procurador y de los honorarios del letrado: respuestas a lagunas y deficiencias legales», en Diario La Ley, núm. 6891, 26 febrero 2008, págs. 1-8. Bonet NAVARRo, J., El procedimiento por "cuenta manifestada». Reclamación de la cuenta del procurador y de los honorarios del abogado, La Ley, Madrid, 2010. MARTín CONTRERAs, L., Las costas procesales: tasación de costas en todas los órdenes jurisdiccionales, provisión de fondos y jura de cuentas, Bosch, Hospitalet de Llobregat, 2015.

${ }^{6}$ Afirma el ATS, Sala 1. ${ }^{\text {a }}$, Secc. 1, de 9 de septiembre de 2015 (Ponente: Sr. SeIJAS QUINTANA), que "lo resuelto en este procedimiento sumario y privilegiado no goza del efecto de cosa juzgada, pudiendo ser discutidos sus extremos en juicio declarativo posterior, donde se resuelva la controversia y las pretensiones de las partes, con posibilidad plena de prueba y de alegaciones».

${ }^{7}$ Bonet Navarro, J., El procedimiento por «cuenta manifestada»..., cit., pág. 276. 
o clientes las cuentas y las minutas que generaban los procesos en los que habían intervenido ${ }^{8}$.

Esta regulación nace ya, y se mantiene durante más de un siglo, en el centro de la polémica doctrinal y al filo de la navaja en lo referente a la garantía de los derechos de las personas y hasta incluso de la constitucionalidad. Esto se debe a que, al margen de ciertos problemas prácticos relevantes ${ }^{9}$, cuando categóricamente disponía que «verificado el pago, podrá el deudor reclamar cualquier agravio...», parecía derivarse la vigencia del llamado principio solve et repete $\mathrm{y}$, de ese modo, la exclusión de cualquier posibilidad de oposición ${ }^{10}$. No obstante, las objeciones a esta severa y restrictiva interpretación pronto se hicieron patentes. Por ejemplo, Prieto Castro ponía de manifiesto que «la aplicación estricta del principio solve et repete equivale poco menos que a una condena definitiva» ${ }^{11}$. Y en cualquier caso, si a esta limitación defensiva añadimos que el procedimiento se consideraba en general "privilegiado» para favorecer exclusivamente a unos concretos profesionales jurídicos como abogados y procuradores, no podía extrañar que quedara en tela de juicio sobre todo una vez en vigor la Constitución española de 1978.

${ }^{8}$ Disponía el artículo 8 LEC 1881 que «cuando un Procurador tenga que exigir de su poderdante moroso las cantidades que éste le adeude por sus derechos y por los gastos que le hubiere suplido para el pleito, presentará ante el Juzgado o Tribunal en que radicare el negocio cuenta detallada y justificada; y jurando que le son debidas y no satisfechas las cantidades que de ella resulten y reclame, mandará la Sala o el Juez. que se requiera al poderdante para que las pague, con las costas, dentro de un plazo, que no excederá de diez días, bajo apercibimiento de apremio. Igual derecho que los procuradores tendrán sus herederos respecto de los créditos de esta naturaleza que aquéllos les dejaren. Verificado el pago, podrá el deudor reclamar cualquier agravio, y si resultare haberse excedido el Procurador en su cuenta, devolverá el duplo del exceso con las costas que se causen hasta el completo resarcimiento». Asimismo, según el artículo 12 LEC 1881, "los abogados podrán reclamar del Procurador y, si éste no interviniera, de la parte a quien defiendan, el pago de los honorarios que hubieren devengado en el pleito, presentando minuta detallada y jurando que no le han sido satisfechos. Deducida en tiempo esta pretensión, el Juez o Tribunal accederá a ella en la forma prevenida en el art. 8; pero si el apremiado impugnare los honorarios por excesivos, se procederá previamente a su regulación, conforme a lo que se dispone en los arts. 427 y siguientes».

${ }^{9}$ Véase, por ejemplo, MuÑoz SABATÉ, Ll., «Riesgos y posible inconstitucionalidad del art. 8 sobre jura de cuentas de unos honorarios de abogado de 5 millones de pesetas pagados por su procurador», en Revista Jurídica de Catalunya, 1987, págs. 541-6.

${ }^{10}$ Así Guasp Delgado, J., Comentarios a la Ley de Enjuiciamiento Civil, I, Aguilar, Madrid, 1943, págs. 146-152 y 180-2.

${ }^{11}$ Prieto CASTRO y FerRÁNDIZ, L., "La jura de cuentas en general y aplicada a profesionales no jurídicos», en Estudios y comentarios para la teoría y la práctica procesal civil, II, Reus, Madrid, 1950, pág. 619. 
La STC 110/1993, de 25 de marzo, se pronunció sobre la cuestión de inconstitucionalidad en relación con los artículos 8 y 12 LEC 1881 por vulneración de los artículos 14 y 24 de la Constitución ${ }^{12}$. Aunque no exenta a su vez de críticas ${ }^{13}$, interpretó las expresiones "verificado el pago, podrá el deudor reclamar cualquier agravio» (artículo 8 LEC 1881) y «si el apremiado impugnare los honorarios por excesivos, se procederá previamente a su regulación» (art. 12 LEC 1881), para concluir que no eximían al órgano jurisdiccional de su deber de controlar los presupuestos de admisibilidad en este procedimiento, ni tampoco impedían al deudor introducir motivos de oposición tanto de carácter procesal como de fondo. Así, con el sistema LEC 1881, la técnica de la «jura de cuentas» era solve et repete, si bien atemperada por la doctrina del Tribunal Constitucional que, en una resolución interpretativa, introducía la posibilidad de oposición.

Otra cosa era la concreción del ámbito de estas posibilidades defensivas. Hasta el punto no quedaba definido que el propio Tribunal Constitucional tuvo que pronunciarse en diversas ocasiones sobre este punto, como en las SSTC $12 / 1997$ y $184 / 2002$. Y aunque nunca llegó a fijar con exactitud su alcance, con la LEC 1881 parecía claro que la cognición no era completa pues, como señala literalmente la última de las sentencias citadas, "la posibilidad de oponer estas excepciones... no puede interpretarse en un sentido tan amplio como para admitir que estas alegaciones se extiendan a la genérica impugnación de los honorarios debidos».

Avanzándose considerablemente a su tiempo, Prieto Castro, mucho antes de esta jurisprudencia constitucional, entendió ya que «la única posibilidad de hacer que la desnuda regulación legal se matice de detalles y diferenciaciones que, por lo demás, encuentran... puntos de apoyo muy convincentes en la misma Ley procesal-, con cuyo auxilio el procedimientos se perfile y reciba un contorno de mayor autoridad $y$

12 Prieto Castro y Ferrándiz, L., «El procedimiento privilegiado de exacción de los arts. $7 .^{\circ}, 8 .^{\circ}$, y $12 .^{\circ}$ de la Ley de Enjuiciamiento Civil», II, Reus, Madrid, 1950, pág. 578 , se había adelantado a esta sentencia cuando defendía y argumentaba mucho antes que «el procedimiento de los arts. 8 y 12 LEC 1881, es defendible sin esfuerzo alguno. Abogado y Procurador... hemos de considerarlos como coadyuvadores de la obra de la justicia, y en tal sentido si son partícipes de algún beneficio-a partir de la dignidad misma del ministerio- también les alcanzan deberes y responsabilidades que los extraños a la actividad jurisdiccional no soportan».

${ }^{13}$ Entre otros, Montero Aroca, J., "Sobre la constitucionalidad de la jura de cuentas (Comentario a la Sentencia 110/1993, de 25 de marzo», en Derecho Privado y Constitución, núm. 2, enero-abril, 1994, págs. 283-304. Y con ocasión de la STC 12/1997, DíEz-Picazo GimÉnez, I., «Extensión de las posibilidades de defensa en el procedimiento de jura de cuentas», en Tribunales de Justicia, 1997, núm. 6, pág. 697. 
justicia, igualmente en su tratamiento analógico con el procedimiento monitorio» ${ }^{14}$. Concepción que, por la justicia material que implicaba, efectivamente se encontraba en la base de la citada sentencia del Tribunal Constitucional 110/1993 cuando imponía control de oficio y a instancia de parte de los presupuestos del procedimiento de «jura de cuentas», y también, posteriormente, en la configuración de este procedimiento que ofreció años más tarde la vigente Ley de Enjuiciamiento Civil 1/2000 (en adelante LEC), donde se instrumenta la técnica monitoria y se permite indubitadamente la oposición solamente con algunos límites probatorios.

La LEC 1/2000, en vigor desde el 8 de enero de 2001, supuso una mejora considerable en relación con el anterior sistema, aunque mantiene algunos defectos regulatorios puntuales que han sido subsanados en su mayoría mediante la reforma operada por la Ley 42/2015 a la que después haré referencia. A pesar de ello, la jurisprudencia ha sostenido ocasionalmente al menos que la regulación de los mismos artículos 34 y 35 LEC no difieren sustancialmente de la que se contenía en los arts. 8 y 12 LEC de $1881^{15}$, que era aquellos que -recordemos- establecían el solve et repete solo matizado por la labor interpretadora de la jurisprudencia y particularmente por la citada STC 110/1993. Y como se partía de la idea de un proceso sumario sobre el que, como tal, podrá conocerse en un ulterior plenario, lo que la repetida STC 110/1993 estableció como mínimo ámbito de oposición para considerar el procedimiento como respetuoso de principios y derechos constitucionales tan relevantes como la igualdad y el derecho de defensa, se tomaron como máximos admisibles. No se tenía en consideración con ello que tan relevante sentencia del Tribunal Constitucional solamente se refirió a meros ejemplos y en modo alguno a máximos en el ámbito de las defensas como se pretende. De hecho, se refería expresamente, entre otros, a «tales supuestos $u$ otros semejantes como serían, por ejemplo, el pago o la prescripción del art. 1967.1. a del Código Civil». Lo bien cierto es que si la vigente regulación de los artículos 34 y 35 LEC no difería de la precedente, como entendía la jurisprudencia, la consecuencia no era otra más que, a pesar de que dichos preceptos no establecen limita-

${ }^{14}$ Prieto CAStro y Ferrándiz, L., «El procedimiento privilegiado de exacción de los arts. $7 .^{\circ}, 8 .^{\circ}$, y $12 .^{\circ}$ de la Ley de Enjuiciamiento Civil», cit., pág. 570.

${ }^{15}$ Las SSTS, Sala 4. ${ }^{\mathrm{a}}$, núm. 7050/2004, de 3 de noviembre (de la Secc. 3. ${ }^{\mathrm{a}}$ ), y 7899/2004, de 7 de diciembre (de la Secc. $1 .^{\text {a }}$ ), afirman idénticamente que «la normativa en la materia (arts. 34 y 35) no difiere sustancialmente de la que se contenía en los arts. 8 y 12 de la Ley de 1881; únicamente, la actual resulta más elaborada y explícita que la precedente, al haber acogido la doctrina sentada por el Tribunal Constitucional, entre otras, en su Sentencia número 110 de 25 de marzo de 1993». 
ción alguna en los motivos de oposición, las defensas admisibles quedaban limitadas a las que expresamente mencionaba la célebre STC 110/1993.

Ciertamente las similitudes de los primeros párrafos de los artículos 8 LEC de 1881 y 34 LEC, como las de los artículos 12 LEC de 1881 y 35 LEC, son patentes. Y, al margen de los matices que introdujo la reforma operada por la Ley 13/2009, la redacción es idéntica salvo algunas expresiones sinónimas como "pleito» $\mathrm{y}$ «negocio» que se sustituyen por su equivalente "asunto». No obstante, los cambios habían sido en realidad profundos. Además de sustituir el juramento por la mera manifestación, suprime el famoso solve et repete ${ }^{16}$, y la posibilidad por la cual, verificado el pago, podrá el deudor reclamar cualquier agravio, y si resultare haberse excedido el procurador en su cuenta, devolverá el duplo del exceso con las costas que se causaren hasta el completo resarcimiento. Y, sobre todo, la LEC establece el carácter sumario en la limitación de los medios de prueba no en los motivos de oposición. Por tal motivo, esta limitación defensiva de creación jurisprudencial traslada el debate de la oposición a un ulterior declarativo, superponiéndose así la tradición de una regulación derogada frente al derecho vigente ${ }^{17}$.

Sin embargo, al margen de mantener algunos defectos regulatorios más o menos puntuales y de las referidas dudas interpretativas, resulta indudable que la LEC al menos zanjó cualquier duda de constitucionalidad que podía haberse achacado al viejo procedimiento de «jura de cuentas». En los primeros años del siglo XXI, justo desde que entra en vigor la LEC y hasta que fue reformada por Ley 13/2009, los artículos 34 y 35 LEC regulan un proceso judicial «de cuenta manifestada» que instrumenta la técnica monitoria y que, como tal, es apto para que el deudor ejercite su derecho de defensa alegando motivos de oposición tanto procesales como materiales, además sin limitaciones al menos desde una lectura literal de los citados artículos 34 y 35 LEC. Y si algún motivo de oposición fuera excluido por alguna suerte de restrictiva interpretación, en el peor de los casos, tendría que iniciarse el correspondientes proceso plenario posterior para su debate.

${ }^{16}$ Garnica Martín, J. F., "Cuenta del Procurador», en Comentarios a la nueva Ley de Enjuiciamiento Civil. Art. 1 al 280 (coor:: Fernández-Ballesteros, Rifá y Valls), Iurgium-Atelier, Barcelona, 2000, pág. 349.

${ }_{17}$ Bonet Navarro, J., El procedimiento por «cuenta manifestada». Reclamación de la cuenta del procurador y de los honorarios del abogado, cit., págs. 298-312. 


\section{EL RETORNO DE LA POLÉMICA. EL SEÑORÍO ABSOLUTO DEL «SECRETARIO JUDICIAL» A PARTIR DE LA LEY 13/2009}

No alcanzó a una década la situación descrita. La Ley 13/2009, de 3 de noviembre, de reforma de la legislación procesal para la implantación de la nueva Oficina judicial, devolvió la polémica al procedimiento que nos ocupa.

Esta reforma no se limitó a este procedimiento, afectó a prácticamente todo el sistema procesal. Como se afirma en el preámbulo de la citada Ley "se trata, en sintesis, de que los Jueces y Magistrados dediquen todos sus esfuerzos a las funciones que les vienen encomendadas por la Constitución: juzgar y hacer ejecutar lo juzgado. Para ello es preciso descargarles de todas aquellas tareas no vinculadas estrictamente a las funciones constitucionales que se acaban de señalar... se atribuirán a otros funcionarios aquellas responsabilidades y funciones que no tienen carácter jurisdiccional». Esto implica reconocer que los jueces y magistrados antes realizaban «tareas» que no eran jurisdiccionales. Se ha de suponer que es el caso del procedimiento de «manifestación de cuentas» que nos ocupa, puesto que, si el legislador se limitó a sustituir el órgano competente, sin modificar el procedimiento ni las consecuencias y eficacia del mismo, solamente debía ser porque el juez debía ejercer funciones no jurisdiccionales en este procedimiento.

Parecido ocurrió con el proceso monitorio de los artículos 812 a $818 \mathrm{LEC}^{18}$. Y en efecto, se intentó argumentar que no se trataba de un verdadero proceso, por carecer de carácter jurisdiccional. En esa línea, entendiendo que desde 2009 el monitorio ya era de hecho -en su opinión- un procedimiento de jurisdicción voluntaria, Banacloche ${ }^{19}$ todavía va más allá y justifica «dar un paso más en esa línea de desjudicialización de la técnica monitoria y permitir que un procedimiento parecido, con efectos también similares, pueda desarrollarse al

${ }^{18}$ Herrero Perezagua, J. F., Lo jurisdiccional en entredicho, cit., 2014, págs. 68-74. Antes y más específicamente, Ídem, «La reforma del proceso monitorio por la Ley 13/2009», en Revista Aranzadi Doctrinal, núm. 6, octubre 2010, págs. 81 y ss.

${ }^{19}$ Banacloche Palao, J., Los nuevos expedientes y procedimientos de jurisdicción voluntaria. Análisis de la Ley 15/2015, de 2 de julio, La Ley, Madrid, 2015, pág. 258. Y en esa misma línea parece inscribirse PILlado GonzálEz, E., «Procedimiento notarial de reclamación de deudas dinerarias no contradichas», en Diario La Ley, núm. 8782, 14 de junio de 2016, pág. 6, cuando afirma que «se presenta como lógica consecuencia de la propia evolución del juicio monitorio que a lo largo de sus distintas modificaciones ha llegado a ser competencia exclusiva del letrado de la Administración de Justicia, salvo intervenciones puntuales del juez, lo que lleva a calificarlo como un expediente de jurisdicción voluntaria». 
margen de los juzgados». Sin embargo, la negación de la naturaleza jurisdiccional al proceso monitorio se enfrentaba a la dificultad, cuando no imposibilidad, para explicar la razón por la que de un procedimiento no jurisdiccional pudiera derivar un efecto de cosa juzgada (art. 816.1 LEC) y una ejecución como si de una sentencia se tratare (art. 816.2 LEC). Además, la doctrina mayoritaria se ha mostrado rotunda reconociendo que el proceso monitorio, lejos de ser un expediente de jurisdicción voluntaria, es un proceso de carácter declarativo si bien especial ${ }^{20}$. Nótese como el monitorio regulado en los artículo 812 a 818 LEC es denominado en el texto de la LEC como "proceso», tanto en el Título III y en el Capítulo I, como también en el texto de los artículos 812, 813 y 816 LEC. Es más, como afirma López Sánchez ${ }^{21}$, en su seno se practican "una serie de actividades de enjuiciamiento que entrañan cometidos claramente jurisdiccionales», esto es, decisión sobre la admisión o inadmisión de la demanda o «petición inicial», valoración de la suficiencia documental y de los requisitos de la obligación que funda la pretensión. Todo ello dotado de unas expeditivas consecuencias otorgadas a la actitud que adopte el requerido.

${ }^{20}$ GutiÉRREZ de CABIEDES y FernáNDEZ dE HEREdia («Aspectos históricos y dogmáticos del juicio ejecutivo y del proceso monitorio en España», en Revista de Derecho Procesal, 1972, pág. 567) defendía ya que el monitorio es "un proceso de cognición plenario, si bien abreviado, de naturaleza especial y cuya finalidad es la producción de un título ejecutivo». Y actualmente también, entre otros muchos, RoBlEs GARzón, J. A., «Los procesos especiales. El proceso monitorio», en Comentarios prácticos a la nueva Ley de Enjuiciamiento Civil (coor.: CABAÑas), Madrid, 2000, págs. 722-8. AsENcio Mellado, J. M., «El proceso monitorio», en Derecho Procesal Civil. Parte Segunda, Valencia, 2001, pág. 282. ToMÉ GARCíA, J. A., «El proceso monitorio en la nueva Ley de Enjuiciamiento Civil», en Revista de Derecho Procesal, 2000, pág. 446. Gómez AmIGO, L., «La introducción del proceso monitorio en el sistema procesal español», en Actualidad Civil, 38, 18 a 24 octubre 1999, págs. 1178 y 1181. Hinojosa SEgovia, R., «El proceso monitorio en la nueva Ley de Enjuiciamiento Civil», en Revista de Derecho Procesal, núms. 1-3, 2001, págs. 305-6. Correa Delcasso, J. P., «El proceso monitorio", en Instituciones del nuevo proceso civil, IV (coor.: ALONSo-CuEviLlas), Barcelona, 2000, págs. 188-92. En la misma línea, Bonet NAVARRo, J., Los procedimientos monitorios civiles en el derecho español, Thomson-Reuters Aranzadi, Cizur Menor, 2014, págs. 27-33. Y Gómez CoLOMER, J. L., «El proceso monitorio», en Derecho Jurisdiccional, II (con Montero, Montón y BARONA), Valencia, 2000, págs. 758-9, si bien matiza que en caso de que no comparezca o comparezca y no pague, la naturaleza de proceso declarativo especial, "se transforma... en una ejecución, que a su vez es especial también. Y si formula oposición, el proceso se transforma a su vez en un proceso de declaración ordinario».

${ }^{21}$ LÓPEZ SÁNCHEZ, J., "Naturaleza jurídica de los procesos monitorio y cambiario», en Estudios Jurídicos. Secretarios Judiciales, VII-2001, Madrid, 2001, págs. 575-6. Concluye que el carácter de procedimiento encaminado a solventar una situación litigiosa le atribuye una naturaleza claramente jurisdiccional que, en su opinión, exige su conocimiento por jueces y magistrados. 
Siendo así, la atribución al Letrado de la Administración de Justicia de su conocimiento podría suponer un ejemplo de invasión del ámbito de ejercicio de la potestad jurisdiccional. Sin embargo, en este caso concurren circunstancias que, diversamente a lo que ocurre con el procedimiento de «manifestación de cuentas» a pasar de que instrumente también la técnica monitoria, permiten llegar a otra conclusión. En efecto, partiendo de su formación técnica, se explica la intervención del Letrado de la Administración de Justicia en el control judicial al que se ve sometido ${ }^{22}$. Y en efecto, la intervención judicial gravita siempre controladora. Así, conforme al artículo 815.1 LEC, cuando los documentos aportados con la petición no fueran de los previstos en el apartado 2 del artículo 812 o no constituyeren un principio de prueba del derecho del peticionario, el Letrado-Secretario «dará cuenta al juez para que resuelva lo que corresponda sobre la admisión a trámite de la petición inicial»; en virtud del artículo 815.4 $\mathrm{LEC}^{23}$, al que posteriormente me referiré con atención, si la reclamación de la deuda se fundara en un contrato entre un empresario o profesional y un consumidor o usuario, el Letrado-Secretario, con carácter previo dará cuenta al juez para que, sin perjuicio de su potestad de oficio, pueda «apreciar el posible carácter abusivo de cualquier cláusula que constituya el fundamento de la petición o que hubiese determinado la cantidad exigible»; o, conforme al artículo 818 LEC, la oposición será decidida judicialmente -y con efecto de cosa juzgadaen «juicio que corresponda». En fin, puede decirse que las funciones «parajudiciales» atribuidas al Letrado de la Administración de Justicia, además de ser relativamente sencillas y equiparables al impulso procesal en muchos aspectos, sobre todo son de mera colaboración con el titular de la potestad jurisdiccional, a cuya supervisión se so-

${ }^{22}$ Como señala Pillado GonzÁlez, E., «Procedimiento notarial de reclamación de deudas dinerarias no contradichas», cit., pág. 3, "no por ello se han reducido las garantías para el ciudadano, pues los letrados de la Administración de Justicia forman un cuerpo técnico con formación especializada que les cualifica suficientemente para su desempeño. A esto se añade, además, que todas las resoluciones del letrado de la Administración de Justicia podrán ser controladas por el juez a través, no sólo de la declaración de nulidad, sino también del nuevo recurso de revisión introducido por esta misma Ley 13/2009, en el art. 454 bis LEC».

${ }^{23}$ Introducido por el apartado setenta y seis del artículo único de la Ley 42/2015, de 5 de octubre, de reforma de la LEC, y ante la previsión del varapalo que se prevenía y que posteriormente vino con la Sentencia del Tribunal de Justicia de la Unión Europea, Sala 1. a, de 18 de febrero de 2016, en la que, entre otras cosas, se afirma que "la Directiva 93/13 debe interpretarse en el sentido de que se opone a una normativa nacional... que no permite al juez que conoce de la ejecución de un requerimiento de pago apreciar de oficio el carácter abusivo de una cláusula contenida en un contrato celebrado entre un profesional y un consumidor, cuando la autoridad que conoció de la petición de juicio monitorio carece de competencia para realizar tal apreciación». 
mete. Y solo esta colaboración es la que salva de la inconstitucionalidad al proceso monitorio gestionado por este alto funcionario.

Lamentablemente, el protagonismo del Letrado de la Administración de Justicia en el procedimiento "de manifestación de cuentas» que nos ocupa es completo y absoluto hasta el punto de excluir cualquier intervención judicial. La Ley 13/200 graciosamente le otorgó el señorío sobre el mismo, sin concurrir la atenuante de actuar colaborativamente con el titular de la potestad ${ }^{24}$. Y por mucho que el procedimiento tenga un objeto accesorio o derivado de otro proceso, la determinación imperativa y vinculante de lo que corresponde pagar al representado por procurador o al defendido por letrado, haya o no oposición, implica actuar el derecho objetivo en el caso concreto con «heterotutela». Tal actividad puede ser más o menos engorrosa, gustar o no a los jueces y magistrados pero, como más adelante se desarrollará, forma parte de la función «juzgar» que por ser jurisdiccional corresponde exclusivamente a jueces y magistrados en los términos del artículo 117.3 CE.

\section{UNA OPORTUNIDAD PERDIDA, EL REFORZAMIENTO DEL PODER DEL LETRADO-SECRETARIO EN LA REFORMA OPERADA POR LA LEY 42/2015, DE 5 DE OCTUBRE}

Al margen de la reforma que perpetró la citada Ley 13/2009, es ley 42/2015, de 5 de octubre, de reforma de la Ley 1/2000, de 7 de enero, de Enjuiciamiento Civil, la que afrontó por primera vez una reforma de calado sobre lo que hasta entonces había sido el proceso "por cuenta manifestada», para reducirlo al mero "procedimiento» o "expediente» regulado en los artículos 34 y 35 LEC.

En general, la reforma operada por la Ley 42/2015 puede afirmarse que mejora significativamente la regulación precedente. En síntesis, introduce coherencia a la legitimación, otorgándola no solo a los

${ }^{24}$ Por ello Domínguez RuIz, L., «Cláusulas abusivas y procedimiento para reclamar los honorarios de los abogados: ¿Es posible el control de oficio por el letrado de la administración de justicia?», en Diario la Ley, núm. 8860, 10 de noviembre de 2016, pág. 4, con cita de Bonet NaVARRo, J., Los procedimientos monitorios civiles en el Derecho español, cit., págs. 258-265; y Banacloche PalaO, J., Los nuevos expedientes y procedimientos de jurisdicción voluntaria. Análisis de la Ley 15/2015, de 2 de julio, cit., págs. 25-26, afirma que "podemos decir que el procedimiento para reclamar los honorarios de los abogados, así como la cuenta de los procuradores, pasa de tener una naturaleza jurisdiccional a una naturaleza administrativa o de jurisdicción voluntaria». Otra cosa es que la atribución competencial, y el cambio de naturaleza que implica, sea acorde con el principio de exclusividad de la potestad jurisdiccional. 
herederos del procurador sino también a los del abogado ${ }^{25}$, subsanando así un olvido histórico que ha ido arrastrándose más de un siglo; otorga fundamento legal al carácter facultativo de la postulación en este procedimiento ${ }^{26}, \mathrm{y}$ elimina coherentemente la previsión por la que se sumarán las $\operatorname{costas}^{27}$; recuerda que la impugnación de la cuen-

${ }^{25}$ El trato desigual se intentaba explicar en que el procurador, a diferencia del abogado, asumía con su encargo ciertas obligaciones económicas que se transmiten mortis causa. Así lo mantenían, vigente la LEC de 1881, MARTínez MEGÍAs, R. y RodRíGUEz Monteys, J. M., La jura de cuentas. Honorarios profesionales de abogados y procuradores, cit., pág. 122. Y ya con la LEC han mantenido esta consideración DAZA Velázouez de CAStro, R., Comentarios a la Ley de Enjuiciamiento Civil (artículos 1 al 98), Comares, Granada, 2003, pág. 207. MarTín ConTreras, L., La tasación de costas y la liquidación de intereses y sus impugnaciones en los órdenes jurisdiccionales civil, penal, contencioso-administrativo y social (Legislación, doctrina, jurisprudencia y casos prácticos), Comares, Granada, 5. a ed., 2005, pág. 339. Pérez UreÑa, A. A., «Los artículos 34 y 35 LEC. La llamada jura de cuentas», en Práctica de tribunales: revista de derecho procesal civil y mercantil, núm. 48, pág. 44. Sin embargo, el agravio comparativo era criticado por la mayoría de la doctrina. Con la LEC de 1881, PRIETO CASTRO Y FERRÁNDIZ, L., «El procedimiento privilegiado de exacción de los artículos $7 .^{\circ}, 8 .^{\circ}$, y 12. ${ }^{\circ}$ de la Ley de Enjuiciamiento Civil», cit., pág. 585. Y actualmente, han mantenido similar posición crítica, entre otros, ILLESCAS RUS, A. V., «La cuenta y la minuta jurada. Tutela sumaria de los créditos de Procuradores y Abogados», en Sepín LEC Forum. Ley de Enjuiciamiento Civil, núm. 36, diciembre 2003, pág. 30. ACHÓN BRuÑén, M. J., «Los procedimientos de reclamación de la cuenta del procurador y de los honorarios del letrado. Respuesta a lagunas y deficiencias legales», cit., pág. 2. Por su parte, Cedeño HeRnán, M., Retribución de Abogados y Procuradores: la llamada «Jura de Cuentas», cit., pág. 78, critica la sucesión en la legitimación pues no se justifica en cuanto a la condición de colaboradores.

${ }^{26}$ Los escasos argumentos que se aportaban para intentar fundar el carácter no preceptivo de la postulación adolecía de importantes carencias. Además de la sencillez del procedimiento, básicamente se centra en la condición profesional del legitimado activo (por ejemplo, SAP Madrid, Secc. 10. ${ }^{a}$, núm. 590/2008 de 7 de octubre), pero sin justificar por qué ha de eximirse la actuación mediante procurador, en caso de que el legitimado fuera el mismo procurador y, sobre todo, cuando lo sean sus herederos que puedan no ser técnicos en derecho. En realidad, el único e inconfesable fundamento del carácter facultativo de la postulación se encontraba únicamente en la tradición. De hecho, Manresa y Navarro, J., M. ${ }^{a}$, Comentarios a la Ley de Enjuiciamiento Civil: reformada con las bases aprobadas por la ley de 21 de junio de 1860, I, Reus, Madrid, 1943, págs. 121-2, nota I, a la pregunta de si es necesaria la dirección letrada en las «diligencias de cuenta jurada», cita la Sentencia del Tribunal Supremo de 1 de abril de 1903, que resuelve la duda negativamente de modo que los honorarios devengados por el letrado en la dirección del «expediente» no son exigibles al cliente moroso que haya dado lugar a él. Posteriormente, hace lo propio PRIETO CASTRO Y FERRÁNDIZ, L., "El procedimiento privilegiado de exacción de los artículos 7. , 8. ${ }^{\circ}$, y $12 .^{\circ}$ de la Ley de Enjuiciamiento Civil», cit., pág. 587, quien, con base en la misma sentencia y se limita a afirmar que la simple solicitud «no requiere la intervención de abogado».

${ }^{27}$ Incluso se elimina la misma previsión del punto 3 de los artículos 34 y 35 LEC, omitiendo que en el supuesto de que se despache ejecución, se incluyan «las costas». Se supone que esto se refiere a las costas del procedimiento previo, pues no se justifica que el proceso de ejecución derivado de este procedimiento esté exento de las mismas. 
ta del procurador es únicamente "por ser indebida» ${ }^{28}$, previsión que debería terminar con cualquier práctica que confunda cuenta del procurador indebida con excesiva, aunque el procurador pretenda cobrar más de lo que le corresponde según arancel; en coherencia con la contestación escrita en el juicio verbal, refuerza la contradicción permitiendo que también el acreedor, y no solo el deudor, pueda alegar lo que estime oportuno sobre la impugnación en el plazo de tres días; y, otorga cobertura legal al apercibimiento de ejecución en caso de pasividad, estableciendo en concreto las consecuencias de la falta de oposición, se ha de entender que también por la ausencia del pago aunque sorprendentemente no se exprese, esto es, que si «el poderdante» o "el deudor de los honorarios» no formularen "oposición dentro del plazo establecido, se despachará ejecución por la cantidad a que ascienda la cuenta».

No obstante, esta reforma omite cualquier referencia al problema de la constitucionalidad de este procedimiento. Es más, por el contrario, todavía refuerza si cabe las funciones del «Secretario Judicial» ${ }^{29}$. En efecto, se modifica la redacción del artículo 34.2 LEC para expresar que, una vez presentada la cuenta por el procurador, el «Secretario Judicial» requerirá al poderdante para que pague dicha suma, pero siempre que la cuenta haya sido "admitida». Se aclara así la obviedad de que este procedimiento requiere un trámite de admisión, esto es, una decisión valorativa por la que se controlan sus presupuestos. Sin embargo, de este modo introduce un nuevo agravio comparativo en la literalidad de la ley entre abogado y procurador, pues la previsión se circunscribe al artículo 34 LEC, manteniéndose inalterado el tenor del artículo 35.2 LEC por el que "presentada esta reclamación, el secretaria judicial requerirá al deudor...»

Aunque no se justifica en absoluto que el procedimiento de reclamación de minutas por el abogado sea admitido de forma automáti-

${ }^{28}$ Parece que algunos operadores no han llegado a comprender que la impugnación de la cuenta del procurador única y exclusivamente puede se impugnada por indebidos y, en ningún caso, por excesivos, a pesar de que la cuenta sea superior -o exceda- a la debida. Al regularse en arancel, la procedencia o no de este arancel, junto a si el acto fue o no necesario en atención a las circunstancias, así como, habiéndose realizado el acto y siendo necesario, si se había aplicado debidamente el baremo sobre el mismo, se convierte meramente en una cuestión jurídica en la que no se justifica en absoluto la aplicación del artículo 246 LEC al que remite el artículo 35.2. III LEC exclusivamente para la impugnación por minuta excesiva de abogado.

${ }^{29}$ Que es como vuelve a denominar a este cuerpo la ley 42/2015, de 5 de octubre, a los cinco días de la entrada en vigor, el 1 de octubre, de la Ley Orgánica 7/2015, de 21 de julio, por la que se modifica la Ley Orgánica 6/1985, de 1 de julio, del Poder Judicial, por la que el cuerpo de Secretarios Judiciales pasaba a denominarse cuerpo de Letrados de la Administración de justicia. 
ca, desde luego esta previsión contribuye a la incoherencia, no obedece a una técnica legislativa rigurosa, ni tampoco previene renovadas dudas interpretativas. Es más, fuerza una interpretación integradora, sin cobertura legal clara, que impida llegar al absurdo de que el requerimiento en el caso de reclamación por el abogado se producirá con alguna suerte de automatismo a todas luces inaceptable. Y lo que es todavía más grave, en lugar de limitar el poder del Letrado-Secretario, todavía lo refuerza, evidenciando más claramente su invasión en la función de «juzgar» que, como se ha recordado y se insistirá, se halla exclusiva y excluyentemente atribuida a los jueces y magistrados en virtud del artículo 117.3 de la Constitución española.

\section{DE FUERA VENDRÁN Y NOS ADVERTIRÁN, LA INADECUACIÓN AL DERECHO DE LA UNIÓN Y LA NECESARIA REFORMA}

La jurisprudencia del Tribunal de Justicia de la Unión Europa ha supuesto en los últimos tiempos una verdadera revolución en el papel que ha de adoptar el órgano jurisdiccional en el control de las cláusulas abusivas que causen, en detrimento del consumidor, un desequilibrio relevante entre los derechos y obligaciones de las partes. Esto es así porque el principio de efectividad del Derecho de la Unión Europea no solo exige facultar la intervención, sino que impone al juez el deber de intervenir, aun cuando no haya sido alegado por las partes en el procedimiento, para declarar el control abusivo de las cláusulas, cualquiera que sea el procedimiento en el que se suscite y cualquiera que sea la fase del procedimiento ${ }^{30}$.

Esta doctrina ha desembocado, primero, en las Leyes 1/2013 y 8/2013, para su adecuación del procedimiento ordinario de ejecución y en el hipotecario; y, por último, en la reforma de la LEC operada por la antes referida Ley 42/2015 en la que, entre otras muchas cosas, modifica el art. 552.1. II LEC, para dar cobertura a la Sentencia del Tribunal de Justicia de la Unión Europea, de 6 de octubre de 2009;

${ }^{30}$ Esta jurisprudencia parte originariamente de la Sentencia del Tribunal de Justicia entonces denominado «de las Comunidades Europeas», de 9 de marzo de 1978, en el caso Simmenthal; y de 14 de febrero, de 27 de junio de 2000 (asuntos acumulados C-240/98, C-241/98, C-242/98, C-243/98 y C-244/98, caso Océano-Murciano Quintero). Y ha sido desarrollada, además de por la Sentencia del Tribunal de Justicia de la Unión Europea de 14 de junio de 2012, en el asunto Banco Español de Crédito, C-618/10, y Auto, de 11 de junio de 2015 (Asunto C-602/13); por numerosas sentencias del mismo órgano, entre otras, la de 4 de junio de 2009, asunto C-243/08, caso Pannon); y de 30 de mayo de 2013 (C-488/11). 
e introduce, por mor de su apartado setenta y seis, el artículo 815.4 LEC, para acomodarlo a la Sentencia del Tribunal de Justicia de la Unión Europea, de 14 de junio de 2012, en el asunto Banco Español de Crédito, C-618/1031.

Este artículo 815.4 LEC dispone que cuando la reclamación de la deuda se funde en un contrato entre un empresario o profesional y un consumidor o usuario, «el Secretario Judicial, previamente a efectuar el requerimiento, dará cuenta al juez para que pueda apreciar el posible carácter abusivo de cualquier cláusula que constituya el fundamento de la petición o que hubiese determinado la cantidad exigible». A continuación, el juez examinará de oficio si alguna de las cláusulas puede ser calificada como abusiva, en tal caso, «dará audiencia por cinco días a las partes. Oídas éstas, resolverá lo procedente mediante auto dentro de los cinco días siguientes». Y si las considerara abusivas «el auto que se dicte determinará las consecuencias de tal consideración acordando, bien la improcedencia de la pretensión, bien la continuación del procedimiento sin aplicación de las consideradas abusivas». Además, el auto que se dicte, «será directamente apelable en todo caso».

El modo con que se ha afrontado la acomodación de este precepto en el ámbito del proceso monitorio es relevante ahora por las indudables afinidades que mantiene con los procedimientos en los que se

${ }^{31}$ Las palabras del punto V del Preámbulo de la Ley 42/2015, a la que nos hemos referido en el punto anterior así lo reconoce cuando literalmente afirma que «la reforma de la Ley de Enjuiciamiento Civil da cumplimiento a la sentencia del Tribunal de Justicia de la Unión Europea, de 14 de junio de 2012, en el asunto Banco Español de Crédito, C-618/10, donde, tras el examen de la regulación del proceso monitorio en España, en relación con la Directiva 93/13/CEE del Consejo, de 5 de abril de 1993, sobre las cláusulas abusivas en los contratos celebrados con consumidores, declaró que la normativa española no es acorde con el derecho de la Unión Europea en materia de protección de los consumidores, en la medida "que no permite que el juez que conoce de una demanda en un proceso monitorio, aun cuando disponga de los elementos de hecho $y$ de derecho necesarios al efecto, examine de oficio -in limine litis ni en ninguna fase del procedimiento- el carácter abusivo de una cláusula sobre intereses de demora contenida en un contrato celebrado entre un profesional y un consumidor, cuando este último no haya formulado oposición». Por esta razón se introduce en el artículo 814 de la Ley de Enjuiciamiento Civil, en un nuevo apartado 4, un trámite que permitirá al juez, previamente a que el secretario judicial acuerde realizar el requerimiento, controlar la eventual existencia de cláusulas abusivas en los contratos en los que se basen los procedimientos monitorios que se dirijan contra consumidores o usuarios y, en su caso, tras dar audiencia a ambas partes, resolver lo procedente, sin que ello produzca efecto de cosa juzgada, como exige la normativa europea. Igualmente, se da cobertura a la sentencia del Tribunal de Justicia de la Unión Europea de 6 de octubre de 2009 y al criterio consolidado en nuestra jurisprudencia al incorporar la posibilidad del control judicial de las cláusulas abusivas en el despacho de ejecución de laudos arbitrales, al igual que ya está previsto para los títulos no judiciales». 
instrumenta la misma «técnica monitoria», como es el de «manifestación de cuentas» regulado en los artículos 34 y 35 LEC que ahora nos ocupa. Y dada la semejanza o identidad entre el proceso monitorio de los artículos 812 a 818 LEC y el procedimiento de manifestación de cuentas de los artículos 34 y $35 \mathrm{LEC}^{32}$, es de prever que las soluciones sean semejantes en ambos casos.

Así, el Letrado de la Administración de Justicia del Juzgado de Violencia sobre la Mujer núm. 1 (único) de Terrassa (Barcelona), en el contexto de un proceso sobre guarda y custodia en la que el abogado presentó minuta detallada reclamando honorarios no satisfechos, no se le plantean al parecer dudas de constitucionalidad sobre la función de juzgar que implica su propia actividad. Sin embargo, sí duda sobre la conformidad del procedimiento que denomina «de jura de cuentas» con el derecho de la Unión Europea puesto que no se considera habilitado para controlar de oficio la existencia de cláusulas abusivas en el contrato celebrado entre el abogado y su cliente. Del mismo modo, entiende que en tal control le está vedado practicar prueba distinta a la documental o pericial. Y en consecuencia de todo esto, presentó tres cuestiones prejudiciales ${ }^{33}$.

En la primera pregunta: "¿se oponen los artículos 34, 35, 207, apartados 2 a 4, de la LEC, al regular el procedimiento gubernativo de jura de cuentas, al artículo 47 de la Carta de los Derechos Fundamentales de la Unión Europea por cuanto se veda la posibilidad de control judicial? En caso de resultar afirmativo: ¿Es el «Secretario Judicial», en el ámbito del procedimiento de los artículos 34 y 35 de la LEC, «órgano jurisdiccional»? Plantea así una duda ahora extremadamente interesante, porque el citado artículo 47 se refiere al derecho a una tutela judicial efectiva y a un juez imparcial en cuanto pone en tela de juicio la propia existencia de este procedimiento en su configuración desde la lamentable reforma 13/2009 de la oficina judicial. Asimismo, en la segunda cuestión se plantea si la regulación del procedimiento de manifestación de cuentas se opone a la normativa europea en materia de cláusulas abusivas y prácticas comerciales desleales, al no haberse previsto su control de oficio; y finalmente, en la tercera, si la

${ }^{32}$ Afirma literalmente la abogada general (http://curia.europa.eu/juris/document/ document.jsf?text $=\&$ docid $=183346 \&$ pageIndex $=0 \&$ doclang $=$ ES $\&$ mode $=$ req $\&$ dir $=\& o$ $\mathrm{cc}=$ first\&part $=1 \& \mathrm{cid}=877551)$ que "el procedimiento que es objeto del presente asunto es semejante al proceso monitorio que era objeto de los asuntos Banco Español de Crédito y Finanmadrid, puesto que este último proceso prevé el traslado de la iniciativa procesal-denominado «inversión del contencioso»-al deudor, de modo que la carga de iniciar un procedimiento contradictorio recae sobre el destinatario del requerimiento de pago si no quiere que éste adquiera carácter ejecutivo».

${ }^{33}$ Asunto C-503/15, Ramón Margarit Panicello contra Pilar Hernández Martínez. 
oposición a la normativa europea se produce por las limitaciones derivadas en materia de medios de prueba admisibles ${ }^{34}$.

Sobre la conformidad del que denomina "procedimiento simplificado nacional de reclamación de honorarios de abogado", o "expediente de jura de cuentas», con la Directiva 93/13/CEE, sobre las cláusulas abusivas en los contratos celebrados con consumidores, la abogada general, Dña. Juliane Kokott, formula conclusiones el 15 de septiembre de 2016 que presentan indudable relevancia, sobre todo si por último las recoge el Tribunal de Justicia de la Unión Europea, como puede ser previsible. Siendo así, el debate se servirá en el modo con que deberá adecuarse la regulación actual a las exigencias europeas. De todos modos, incluso aunque las conclusiones no fueran compartidas por la Sentencia que se dicte, mantiene interés porque reabre el debate sobre el poder que ejerce el Letrado de la Administración de Justicia «juzgando» en este proceso. Así, de forma indirecta, pone en tela de juicio la adecuación constitucional del procedimiento de manifestación de cuentas tal y como se ha configurado tras la reforma que perpetró la repetida Ley 13/2009.

Por lo pronto, la abogada general considera al «Secretario Judicial», como «órgano jurisdiccional». Esto se plantea a los meros efectos de considerar legitimado al Letrado-Secretario para formular las cuestiones prejudiciales, cosa que entiende en contra del criterio del «gobierno español». Pero las consideraciones y argumentos que aporta son reveladores para poner en evidencia el hecho por el que pueda estar invadiendo el ámbito de ejercicio de la potestad jurisdiccional reservado en exclusiva a jueces y magistrados. Se reproducirán ahora las más relevantes en este sentido:

1. ${ }^{\circ}$ Los Letrados de la Administración de Justicia dictan resoluciones ${ }^{35}$.

${ }^{34}$ Estas dos cuestiones son las siguientes: 2) ¿Se oponen los artículos 34 y 35 de la [LEC] a los artículos 6, apartado 1, y 7, apartado 2, de la Directiva [93/13] y a los artículos 6, apartado 1, letra d), 11 y 12 de la Directiva [2005/29], al vedar el control de oficio de las eventuales cláusulas abusivas o prácticas comerciales desleales que contengan los contratos celebrados entre abogados [y] personas físicas que actúan con un propósito ajeno a su actividad profesional?. 3) ¿Se oponen los artículos 34 y 35 de la [LEC] a los artículos 6, apartado 1, 7, apartado 2, y [punto 1, letra q) del anexo] de la Directiva [93/13], al impedir la práctica de prueba en el procedimiento administrativo de «jura de cuentas» para resolver la cuestión?

${ }^{35}$ Si hay oposición, los «Secretarios Judiciales» dictarán decreto fijando la cantidad, pero, como afirma la abogada general, «también dictan resoluciones cuando... al requerir a los deudores para que satisfagan los créditos que previamente han examinado y al despachar la ejecución de los mismos por no haberse formulado oposición. Es de suponer que tales resoluciones también se dictan en forma de decreto». 
2. ${ }^{\circ}$ Las resoluciones tienen eficacia ejecutiva. Además, no serán susceptibles de recurso, esto es, tendrán eficacia de cosa juzgada formal, pero no tendrán eficacia de cosa juzgada material. Si bien esta ineficacia «no obsta en absoluto a su carácter ejecutivo».

3. La eficacia ejecutiva de estas resoluciones será la propia de los títulos judiciales ${ }^{36}$.

4. ${ }^{\circ}$ Aunque los Secretarios Judiciales españoles no pertenecen al poder judicial sino que son funcionarios públicos al servicio del Ministerio de Justicia, desde el punto de vista la Unión, tienen la consideración de órgano jurisdiccional cuando, a los efectos del artículo 267 TFUE, ejerce funciones jurisdiccionales.

Aunque, como se advirtió, formulado a los meros efectos de la legitimación y admisibilidad de la cuestión prejudicial formulada por el

${ }^{36}$ Sostiene la abogada general, al contrario de lo que entiende el gobierno español, "si se sigue cuidadosamente la cadena de remisiones de las disposiciones de la LEC que se ocupan de la ejecución (artículos 517 LEC, 556 LEC y 557 LEC), resulta que las resoluciones de los secretarios judiciales se ejecutarán como resoluciones judiciales». Además, argumenta que «el artículo 557 LEC, apartado 1, remite sólo a «otros documentos con fuerza ejecutiva a que se refiere el número $9 .^{\circ}$ del apartado 2 del artículo 517» y no a las "demás resoluciones «procesales»» que también se mencionan en la misma disposición, puesto que éstas últimas se regulan en el artículo 556 LEC, el cual, según su propio tenor, tiene por objeto precisamente la ejecución de las «resoluciones "procesales»». Y, en fin, concluye argumentando sobre esto que, "los decretos dictados por los secretarios judiciales en la jura de cuentas de acuerdo con los artículos 34 LEC y 35 LEC no están entre los "documentos con fuerza ejecutiva» a que se refiere el artículo 517 LEC, apartado 2, número 9. ${ }^{\circ}$, sino entre las «resoluciones procesales» a que se refiere la misma disposición, puesto que, de conformidad con el artículo 206 LEC, apartado 2, dichos decretos quedan subsumidos en el concepto de "resoluciones» del mismo órgano. Por tanto, a efectos del artículo $556 \mathrm{LEC}$, los decretos dictados por los secretarios judiciales en la jura de cuentas son, sin género de dudas, resoluciones "procesales", por lo que, a la hora de proceder a su ejecución, se han de asimilar a las resoluciones judiciales». Incluso desde una interpretación sistemática se llegaría a esta solución porque «la Ley 13/2009, que trasladó a los secretarios judiciales la competencia para conocer de la jura de cuentas, modificó también el título del artículo 556 $L E C$, que antes era "Oposición a la ejecución de resoluciones judiciales o arbitrales» y ahora es "Oposición a la ejecución de resoluciones "procesales» o arbitrales»; por ello, tal como explica expresamente el preámbulo de la Ley 13/2009, "con el objeto de unificar la terminología y adaptarla a las nuevas competencias del Secretario judicial, se utiliza la expresión "resoluciones 'procesales'», para englobar tanto las resoluciones judiciales [...] como las del Secretario judicial»». Y por último, concluye sobre esto afirmando que «estas palabras prueban la voluntad del legislador español no sólo de transferir a los secretarios judiciales la competencia sobre la jura de cuentas, otrora reservada a jueces y magistrados, sino también de asegurarse de que, de acuerdo con el artículo 556 LEC, la ejecución de las resoluciones dictadas por los secretarios judiciales en dicho procedimiento deba despacharse del mismo modo que la de las resoluciones judiciales». 
«Secretario Judicial», el argumentario sobre esto último se presenta como una especie de decálogo sobre la invasión por parte de este funcionario sobre el ámbito de la jurisdicción reservado en exclusiva a jueces y magistrados. En efecto, la abogada general resalta los caracteres fundamentales de la actuación del «Secretario Judicial», concretándolos en los siguientes:

- Carácter legal y actividad en la que aplica el derecho objetivo en el caso concreto ${ }^{37}$.

- Actuación con suficientes garantías de independencia ${ }^{38}$.

- Carácter contradictorio para resolver una controversia, con valoración de prueba y control de la fundamentación de la reclamación al comprobar el crédito a la vista de los documentos disponibles ${ }^{39}$.

Reforzando este relevante carácter, recuerda con toda razón que la reforma 13/2009 se limitó sustraer al titular de la potestad jurisdiccional la competencia del proceso de «manifestación de cuentas» atribuyéndola al «Secretario Judicial», sin que se alterara el desarrollo del procedimiento ni la eficacia ejecutiva que derivaba del mismo ${ }^{40}$. Asi-

${ }^{37}$ Señala la abogada general que «no existe controversia sobre el origen legal de la actividad de los secretarios judiciales y la permanencia de éstos... tampoco hay duda de que en la jura de cuentas (artículos 34 LEC y 35 LEC) los secretarios judiciales aplican normas jurídica».

${ }^{38}$ Indica que "los secretarios judiciales disfrutan, tanto en relación con su estatuto como en relación con el desempeño de sus funciones en la jura de cuentas, de suficientes garantías como para considerar cumplido el criterio de la independencia... pese a su condición de funcionarios públicos de la Administración de Justicia, en el desempeño de sus competencias en materia de jura de cuentas los secretarios judiciales sí son lo suficientemente independientes como para considerarlos "órganos jurisdiccionales" a los efectos del artículo 267 TFUE».

${ }^{39}$ Señala sobre esto que "la jura de cuentas presenta rasgos que apuntan claramente a su carácter contradictorio. Si bien en teoría es posible que, por no formular oposición el deudor, el abogado obtenga en el procedimiento un título ejecutivo para su reclamación sin que llegue a existir debate contradictorio en cuanto al fondo, el procedimiento pasará a ser contradictorio a más tardar en el momento en que se produzca dicha oposición de la parte contraria, en la medida en que entonces el secretario judicial deberá no sólo comprobar la reclamación del abogado sino también oír a éste... en la jura de cuentas está evidentemente pendiente una controversia: el litigio sobre una reclamación de honorarios presunta o realmente no abonados a un abogado. Por lo tanto, mediante el despacho de la ejecución del crédito o la fijación del importe del mismo los secretarios judiciales desencadenan dicho litigio, llevando a cabo en todo caso también una valoración de la prueba y cierto control de la fundamentación de la reclamación al comprobar el crédito a la vista de los documentos disponible».

${ }^{40}$ Afirma literalmente que «tampoco desvirtúa el carácter contradictorio del procedimiento la circunstancia de que la jura de cuentas fuera atribuida a los secretarios judiciales con la finalidad de descargar a los jueces y magistrados de todas aquellas 
mismo, entiende que el aparente carácter incidental por su dependencia de un pleito anterior que genere los créditos, como tampoco el carácter alternativo del procedimiento que corresponde a todo monitorio, impide ser contradictorio cuando la competencia de los Secretarios judiciales y el carácter vinculante de sus resoluciones no dependen de un acuerdo de las partes ${ }^{41}$. Y de particular interés, por tratarse de un elemento identificador de la jurisdicción como más adelante se señalará, es que afirme rotundamente la abogada general que «la falta de fuerza de cosa juzgada material no resta carácter jurisdiccional a las resoluciones dictadas en la jura de cuentas» ${ }^{42}$.

Como colofón, reconoce que esta atribución competencial en su momento "suscitó un debate a escala nacional sobre la conformidad con el Estado de Derecho de la atribución de competencias cuasijudiciales a órganos dependientes de la Administración de Justicia» ${ }^{43}$. Debate este cuyo fundamento desde luego se mantiene y ahora se reproduce, aunque sea indirectamente, de una forma demasiado patente como para que el legislador se mantenga impasible como hasta ahora.

tareas que no supusieran el ejercicio de funciones jurisdiccionales. Tanto más cuanto que el desarrollo del propio procedimiento y el carácter ejecutivo de la resolución con que concluye no sufrieron cambios en el contexto de su atribución a los secretarios judiciales».

${ }^{41}$ Insiste en que «tampoco el carácter incidental de la jura de cuentas y su dependencia de un pleito anterior son indicios de que el procedimiento, que por ello mismo es semejante a la tasación de costas que conoce bien el Tribunal de Justicia, no sea contradictorio o no sirva para zanjar un litigio pendiente... la competencia de los secretarios judiciales sobre el procedimiento no depende de un acuerdo entre las partes y que sus resoluciones son vinculantes para ellas... a la hora de considerar obligatorio este procedimiento no obsta que, para reclamar sus honorarios, los abogados puedan recurrir a otros procedimientos distintos, puesto que si deciden recurrir a esta vía especial en un asunto, los clientes se ven involucrados necesariamente en el expediente».

${ }^{42}$ Argumenta para ello que "con independencia de que con posterioridad puedan impugnarse en un procedimiento separado, dichas resoluciones de los secretarios judiciales tienen para las partes del expediente indudablemente los mismos efectos que las resoluciones judiciales. Como no son recurribles, tienen fuerza de cosa juzgada formal y en ellas se basan, bien un requerimiento de pago al deudor, que tiene un carácter ejecutivo autónomo, bien, en su caso, la obligación para el acreedor, vinculante por sí misma, de aceptar una reducción de sus honorarios.

${ }^{43}$ Con todo, el debate no fue excesivamente ruidoso. Aunque centradas en las dudas de constitucionalidad, no pasaron de meras referencias y alusiones. Así, BonET NAVARRo, J., "Reclamación litigiosa de honorarios: diagnóstico y terapia ante demasiada patología legal», en El trabajo profesional de los abogados, coor.: BLASco, Tirant lo Blanch, 2012, págs. 172-3, afirma que la reforma «desjudicializa la materia poniéndola en exclusiva y excluyentemente en manos de los Secretarios Judiciales». Cosa que, señala, "permite reflexionar sobre el contenido del art. 117.3 CE y la posible invasión de la función de juzgar». 


\section{CONSIDERACIONES COMPLEMENTARIAS PARA «MACIZAR» EL CARÁCTER JURISDICCIONAL DE LA «MANIFESTACIÓN DE CUENTAS»}

Los argumentos de la abogada general son más que suficientes para entender que la actividad del Letrado de la Administración de Justicia en el procedimiento de los artículos 34 y 35 LEC es jurisdiccional. Como resumidamente afirma: «en la jura de cuentas los secretarios judiciales son, a los efectos del artículo 267 TFUE, "órgano jurisdiccional", puesto que en ese contexto resuelven de manera independiente y autónoma sobre litigios que se dan en procedimientos contradictorios y puesto que dictan en ellos resoluciones de carácter jurisdiccional». Así y todo, puede todavía añadirse algo más para reforzar ese carácter jurisdiccional y, por tanto, la invasión de competencias reservadas en exclusiva a jueces y magistrados. Y es que para afirmar de modo definitivo que su actividad puede considerarse indiscutiblemente como jurisdiccional, es necesario identificar perfectamente tal función. A partir de ahí, se valorará si el procedimiento monitorio para la reclamación de minutas por abogado y derechos y suplidos por el procurador forma parte de la misma. Para ello ha de atenderse con particular énfasis los dos principales criterios para la identificación de la jurisdicción: la irrevocabilidad de la decisión y la actuación con desinterés objetivo, también denominada «heterotutela».

El procedimiento "por cuenta manifestada», tal y como está previsto actualmente en los artículos 34 y 35 de la Ley de Enjuiciamiento Civil, carece de efecto de cosa juzgada. Por tal motivo, sus decisiones son revocables por la jurisdicción mediante el procedimiento que corresponda. La abogada general responde a esta cuestión argumentando que "con independencia de que con posterioridad puedan impugnarse en un procedimiento separado, dichas resoluciones de los secretarios judiciales tienen para las partes del expediente indudablemente los mismos efectos que las resoluciones judiciales. Como no son recurribles, tienen fuerza de cosa juzgada formal y en ellas se basan, bien un requerimiento de pago al deudor, que tiene un carácter ejecutivo autónomo, bien, en su caso, la obligación para el acreedor, vinculante por sí misma, de aceptar una reducción de sus honorarios». Y así es, en efecto. Pero también lo es que la jurisdicción se caracteriza en general por la actuación irrevocable, salvo que expresamente quede excluida. Por tanto, si bien todas las decisiones irrevocables integran la jurisdicción, no todas las revocables quedan fuera de la misma como lo demuestra el hecho de que los procesos sumarios no están dotados de eficacia de cosa juzgada (art. 447.2 a 4 LEC), pero sin duda suponen 
ejercicio de la potestad jurisdiccional. Es más, el criterio de la irrevocabilidad tiene efectos identificadores de la jurisdicción limitados. Si la decisión tiene carácter revocable, será jurisdicción. Pero carecer de tal carácter no significa necesariamente que quede fuera de la misma jurisdicción. Además, no es criterio válido para valorar si una determinada actuación, a pesar de ser irrevocable, no merece ser considerada como jurisdiccional; o si, siendo revocable, merecería serlo. Asimismo, el valor limitado de este criterio se evidencia porque, de ser definitivo, hubiera impedido, por ejemplo, que un órgano administrativo que dictaba resoluciones revocables ante la jurisdicción contencioso-administrativa como es el Consejo de Hombres Buenos de la Huerta de Murcia, adquiriera la categoría de órgano jurisdiccional conforme al artículo 19.4 de la Ley Orgánica del Poder Judicial, introducido mediante la LO 13/1999, de 14 de mayo, en relación con el artículo 125 de la Constitución española ${ }^{44}$. Y tal acontecimiento se produjo sin que su revocabilidad impidiera alcanzar la categoría de órgano jurisdiccional.

En fin, aunque este criterio pueda ser un elemento identificador de la jurisdicción, no es desde luego definitivo. Además, podría conducir a admitir la arbitrariedad de negar al legislador cualquier condicionamiento constitucional para establecer los casos en que la jurisdicción ha de conocer $a b$ initio. Por ello, Ortells estima que la determinación de en qué consiste la potestad jurisdiccional debe tener en consideración el conjunto del texto constitucional y el contexto de la tradición jurídica en el que se inserta, sin que la irrevocabilidad tenga relevancia exclusiva en esta determinación ${ }^{45}$. Así, pues, el carácter revocable por inexistencia de cosa juzgada material no excluye el carácter jurisdiccional del procedimiento por «cuenta manifestada» de los artículos 34 y 35 LEC.

De otro lado, es necesario atender también al criterio de la actuación con desinterés objetivo. Es relevante en la identificación porque

${ }^{44}$ Un fenómeno similar se encuentra en ciernes por cuanto el Ayuntamiento de Orihuela, la Diputación de Alicante y, por último, el 5 de marzo de 2014, el Pleno de «les Corts valencianes», por unanimidad de todos los grupos, han reconociendo el derecho histórico del Juzgado Privativo de Aguas de Orihuela para ser considerado tribunal tradicional y consuetudinario y, por tanto, adquiera la categoría de órgano jurisdiccional. Y en su consecuencia, «les Corts» instaron al "Consell de la Generalitat Valenciana» para que se dirija al gobierno español y recabe la presentación de un proyecto de ley de modificación de la Ley Orgánica del Poder Judicial, solicitando al Congreso de los Diputados y al Senado su apoyo al mismo.

${ }^{45}$ Ortells Ramos, M., «La potestad jurisdiccional», en Introducción al Derecho Procesal (con otros), Thomson Reuters Aranzadi, 6. ${ }^{a}$ ed., Cizur Menor, 2016, págs. 125-6. 
el mero hecho de juzgar implica per se que deba ser un tercero quien realice tal actividad, por ello precisamente se acude al desinterés objetivo o "heterotutela» para identificar la función jurisdiccional ${ }^{46}$. Y como los créditos objeto de este procedimiento son de naturaleza civil, o a lo sumo mercantil, por tanto son de naturaleza jurídico-privada, difícilmente se dirigirá a proteger intereses generales ni, derivadamente, podrá consistirá en ninguna suerte de autotutela administrativa. Como se actúa el derecho objetivo con imparcialidad para resolver conflictos de forma contradictoria y, cuando el acreedor opta por el procedimiento, de forma vinculante y eficaz, puede afirmarse que el Letrado de la Administración de Justicia actúa con desinterés objetivo o mediante «heterotutela» y consecuentemente se tratará de potestad reservada a jueces y magistrados exclusivamente en virtud del artículo 117.3 de la Constitución española.

En este caso, salvo que lo remedie alguna reforma futura, como la que en este trabajo se reclama, ya vimos como el Letrado de la Administración de Justicia no mantiene una función de colaboración con el titular de la potestad jurisdiccional más allá de descargarle de trabajo. Por tanto, en el procedimiento de los artículos 34 y 35 LEC no queda salvada en modo alguno su inconstitucionalidad.

\section{A MODO DE CONCLUSIÓN, LA REFORMA PROCESAL QUE VIENE}

Es probable que se recojan las conclusiones de la abogada general en la Sentencia del Tribunal de Justicia de la Unión Europea. De ser así, se declararán los artículos 34 y 35 LEC contrarios a la Directiva 93/13/CEE, en relación con la Directiva 2005/29/CE y con el artículo 47 de la Carta de los Derechos Fundamentales de la Unión Europea, debido a que quien tiene encomendado «instruir» el procedimiento que denomina «expediente de jura de cuentas» no está habilitado

\footnotetext{
${ }^{46}$ Chiovenda, G., Principios de Derecho Procesal, I (trad.: Casáis), Editorial Reus, Madrid, 1922, págs. 344, 347 y 349. También, Gómez Orbaneja, E., Derecho procesal civil, I (con Herce), Madrid, 1976, págs. 49-53. De la Oliva Santos, A., Derecho Procesal, I (con otros), Centro de Estudios Ramón Areces, Madrid, 2004, pág. 26. ORTELLS RAMOS, M., "Aproximación al concepto de potestad jurisdiccional en la Constitución Española», en Anuario de la Facultad de Derecho de la Universidad de Extremadura, Cáceres, 1984-5, pág. 417. Ahora bien, deberíamos reparar en que los intereses generales, en continua expansión, en ocasiones llegan a solaparse con otros intereses privados. De ese modo, derecho privado y autotutela administrativa no resultan necesariamente incompatibles en todos los casos. Pero no parece que la aplicación del derecho objetivo al caso concreto por el Letrado de la Administración de Justicia en este procedimiento se vea afectado por este solapamiento.
} 
para comprobar de oficio si en el contrato celebrado entre un abogado -o procurador- y un consumidor existen cláusulas abusivas o si se han dado prácticas comerciales desleales.

Esto impondrá de inmediato la necesaria reforma de la legislación interna para llevar a efecto la acomodación del procedimiento de «manifestación de cuentas» al derecho de la Unión. El problema será, en su momento, concretar su alcance para permitir un control de oficio de las cláusulas abusivas cuando proceda, siendo respetuosa con el marco constitucional que también vincula. Es más, aunque tan previsible acontecimiento no llegara a producirse y por último la regulación interna en este punto no se estimara contraria al derecho de la Unión en la Sentencia, todavía quedaría subsistente la necesidad de una reforma en profundidad para reconducir este procedimiento a los cauces de la constitucionalidad.

\section{La propuesta de la abogada general es coherente y parece derivar de la misma que el control de "abusividad" debe residir en el «Secretario Judicial»}

Representantes de los Letrados de la Administración de Justicia han puesto las campanas al vuelo para celebrar las consideraciones de la abogada general, Dña. Juliane Kokott, porque entienden que de algún modo "así se da un paso más» ${ }^{47}$, y, de prosperar la cuestión, «no sólo se van a limitar a realizar funciones de carácter administrativo o de jurisdicción voluntaria, sino también de carácter jurisdiccional» ${ }^{48}$. Y, en efecto, esto mismo es precisamente lo que parece derivar a primera y rápida vista de las propuestas formuladas.

Sin embargo, conviene prestar atención a que las conclusiones de la abogada general lo son meramente «a los efectos del artículo $267 \mathrm{del}$

${ }^{47}$ Esteban, P., «Los Letrados de Justicia pueden controlar las minutas abusivas de los abogados», en Diario La Ley, Sección Hoy es Noticia de 23 de septiembre de 2016, indica que «tras conocerse estas conclusiones, Rafael Lara, presidente del Colegio Nacional de Letrados de la Administración de Justicia, ha declarado al respecto: "Estamos satisfechos. Creemos que esto es un espaldarazo a las competencias que a día de hoy se han concedido a los Letrados de la Administración de Justicia», y ha añadido, en relación a la vieja creencia de que los letrados realizan solo "funciones administrativas", que: "Con esto esperamos que dejen de discutir sobre si en el derecho interno un Letrado puede ejercer determinadas competencias dentro del proceso o no»».

${ }^{48}$ Son palabras de Domínguez RuIz, L., "Cláusulas abusivas y procedimiento para reclamar los honorarios de los abogados: ¿Es posible el control de oficio por el letrado de la administración de justicia?», cit., pág. 16. Se supone que están basadas en las palabras de Rafael Lara antes citadas, pero en realidad las desarrolla, en mi opinión, de forma tan contundente como desorbitada. 
Tratado de Funcionamiento de la Unión Europea», esto es, con el fin de decidir si el Letrado de la Administración de Justicia tiene legitimación para formular cuestiones prejudiciales sobre el procedimiento que nos ocupa ${ }^{49}$. Así, tras analizar su competencia, atribuciones, actividad y estatuto personal en el seno del procedimiento que denomina "expedientes de jura de cuentas», concluye que el Letrado puede ser considerado como «órgano jurisdiccional» y, siempre en el contexto de las exigencias del derecho de la Unión, coherentemente defiende que el mismo Letrado de la Administración de Justicia podrá comprobar de oficio si las cláusulas son abusivas. Todo esto, y como no podía ser de otro modo, se propone a los efectos, y como modo de subsanación de su falta de adecuación al derecho de la Unión, y en modo alguno significa que necesariamente cumpla los estándares de constitucionalidad internos. Cosa esta última que no pretende y desde luego compete a la abogada general. Más bien al contrario, lo que plantea en su argumentario hace todavía más evidente el hecho de que el Letrado de la Administración de Justicia está realizando, desde la reforma operada por la Ley 13/2009 y hasta que el entuerto se remedie, funciones jurisdiccionales que invaden el ámbito reservado constitucionalmente a los jueces y magistrados.

Se ha de compartir que se trata de un «sistema mal definido» por la ley que tiene consecuencias para el ciudadano ${ }^{50}$. Pero en la constante tensión e influencia que ha ejercido el «colectivo» profesional para ir "avanzando» hacia la jurisdicción, se ha tensado tanto la cuerda que ha terminado por romperse. En realidad, la ruptura ya se produjo en el momento mismo en que se puso en práctica la tan repetida Ley 13/2009, si bien ahora la abogada general lo ha puesto en evidencia con suficiente nitidez.

Pero, ¿cómo debería concretarse, según la abogada general, la adecuación al derecho de la Unión?. De entrada, se descarta que se produzca el control de oficio en fase de ejecución, debiéndose situar con carácter previo en el seno de los «procedimientos sustanciados ante los secretarios judiciales». Esto es así tanto por economía procesal como por la efectividad del propio control y cumplimiento de las normas de la Unión, dado que la ejecución no será necesaria cuando

${ }^{49}$ Según palabras de la abogada general, «en el contexto del procedimiento regulado en los artículos 34 y 35 de la Ley 1/2000, de Enjuiciamiento Civil, debe considerarse que los secretarios judiciales sí son "órganos jurisdiccionales» facultados, con arreglo al artículo 267 del Tratado de Funcionamiento de la Unión Europea, para plantear peticiones de decisión prejudicial».

${ }^{50}$ Así lo reproduce Esteban, P., «Los Letrados de Justicia pueden controlar las minutas abusivas de los abogados», cit. 
el deudor pague nada más recibir la resolución ${ }^{51}$. De lo contrario, no situándose el control «en los procedimientos sustanciados ante los secretarios judiciales sino en los procedimientos de ejecución que siguen a éstos favorecería el abono de créditos que, si bien han adquirido carácter ejecutivo gracias a los expedientes de jura de cuentas, pueden tener carácter abusivo o desleal». De ese modo, concluye la abogada general que la Directiva 93/13/CEE, en relación con la 2005/29/CE y con el artículo 47 de la Carta, debe interpretarse en el sentido de que se opone a una normativa nacional en la que, como sucede con la controvertida en el procedimiento principal, «los órganos encargados de instruir los procedimientos mediante los que se resuelve sobre las reclamaciones de honorarios (expedientes de jura de cuentas) no pueden comprobar de oficio».

Aparentemente, según las anteriores consideraciones, parece que solamente son dos las alternativas posibles, esto es, bien entender que la existencia de cláusulas abusivas sólo es controlable por el juez en ejecución, o bien atribuir dicho control al letrado de la Administración de Justicia que es el único que interviene. Y ante esta disyuntiva, quizá "sea la solución por la que finalmente abogue el TJUE, ya que como mantiene la Abogada General diferir el control de las cláusulas abusivas al tribunal que vaya a conocer del proceso de ejecución posterior iría en contra de la protección de los consumidores» ${ }^{52}$.

\section{El control del las cláusulas abusivas por el titular de la potestad jurisdiccional}

Ciertamente, a los efectos del derecho de la Unión, la solución apuntada por la abogada general es coherente con la consideración que atribuye al Letrado de la Administración de Justicia como «órgano jurisdiccional», que modo que controle quien conoce del «expediente de jura de cuenta». Sin embargo, la regulación que adecúe el procedimiento al derecho de la Unión debe respetar además el marco constitucional.

${ }^{51}$ Argumenta la abogada general que «la existencia de una resolución ejecutiva ejerce de por si en el consumidor una presión, que no debe subestimarse, para que cumpla con su obligación de pago, por presunta que ésta sea, y especialmente cuando el procedimiento en el que se emite el título ejecutivo está configurado, según sucede en el presente asunto, como expediente contradictorio que culminará en una resolución de carácter jurisdiccional».

${ }^{52}$ Así se ha pronunciado Domínguez RuIz, L., «Cláusulas abusivas y procedimiento para reclamar los honorarios de los abogados...», cit., págs. 2 y 14. 
De entrada, se presentan como muy significativas en este sentido las palabras de la STC 58/2016, de 17 de marzo, que declara la inconstitucionalidad y nulidad del primer párrafo del art. 102 bis. 2 de la Ley 29/1998, de 13 de julio, reguladora de la jurisdicción contenciosoadministrativa, en la redacción dada por la Ley 13/2009. El motivo de esta declaración se encuentra en que dicho precepto impedía el control judicial de los decretos dictados por los Letrados de la Administración de Justicia al resolver el recurso de reposición interpuesto contra diligencias de ordenación o decretos no definitivos. Del texto de esta sentencia resulta altamente significativo, entre otras cosas, lo siguiente:

1. ${ }^{\circ}$ Parte de que al «Secretario Judicial» corresponden funciones «en materias colaterales a la función jurisdiccional» (Preámbulo de la Ley 13/2009), se le reconoce la facultad de dictar determinadas resoluciones motivadas (decretos) y que «se atribuirán a otros funcionarios aquellas responsabilidades y funciones que no tienen carácter jurisdiccional».

2. Describe el esquema diseñado legalmente, esto es, «la toma de decisiones en el proceso se distribuye entre Jueces y Magistrados, por un lado, y Letrados de la Administración de Justicia, por otro. Se reserva a los primeros, como es obligado, las decisiones procesales que puedan afectar a la función o potestad estrictamente jurisdiccional, que les viene constitucionalmente reservada en exclusiva (art. 117.3 CE); y se atribuye a los segundos, que asumen la dirección de la oficina judicial, aquellas funciones que no tienen carácter jurisdiccional, lo que incluye el dictado de resoluciones procesales que no tengan este carácter».

3. ${ }^{\circ}$ Y, partiendo de ese diseño, concluye que «son los Jueces y Magistrados quienes ejercen en exclusiva la función de juzgar y de hacer ejecutar lo juzgado (art. 117.3 CE); en última instancia, se pretende garantizar que toda resolución del Letrado de la Administración de Justicia en el proceso pueda ser sometida al control del Juez o Tribunal, lo que resulta una exigencia ineludible del derecho a la tutela judicial efectiva garantizado por el art. 24.1 $C E$, así como en los textos internacionales sobre derechos fundamentales y libertades ratificados por España (art. 10.2 CE)».

El Tribunal Constitucional deja bien sentado, como no podía ser de otro modo, que la función jurisdiccional corresponde exclusivamente a los jueces y magistrados. El problema es en qué supuestos se ejerce jurisdicción y, más en concreto, si en el seno del procedimiento de manifestación de cuentas ocurre así. A tal efecto, resulta relevante 
que cuando el Anteproyecto de Ley de reforma de la LEC, de 3 de mayo de 2013, pretendió que las cláusulas abusivas se atribuyeran en realidad al «Secretario Judicial», el Pleno del Consejo General del Poder Judicial, el 11 de julio siguiente, en sus puntos 47 y 48, afirmó no solamente que "no cumple con los términos de la sentencia del TJUE», sino sobre todo que "es una clara invasión de la función jurisdiccional» ${ }^{53}$. Al final, como vimos, el artículo 815.4 LEC, en los casos en que la reclamación de la deuda se fundara en un contrato entre un empresario o profesional y un consumidor o usuario, el «secretario judicial... dará cuenta al juez para que pueda apreciar el posible carácter abusivo de cualquier cláusula... de oficio».

Es cierto que en el proceso monitorio, a diferencia de lo que ocurre en el procedimiento de los artículos 34 y 35 LEC, la gestión del «Secretario Judicial» es de mera colaboración y el juez ejerce un discreto control de su actividad. Sin embargo, a pesar de esta diferencia, de haberlo permitido el marco constitucional, creo que ya se hubiera atribuido al «Secretario Judicial» su conocimiento en el contexto del procedimiento monitorio. Y si no se hizo no parece que fuera por falta de una voluntad política resistente a las aspiraciones del colectivo profesional. Por el contrario, se basó más bien en que la declaración de que una cláusula pueda ser abusiva, tras una actividad probatoria suficiente para alcanzar la convicción, sin duda supone «juzgar», en el sentido de aplicar el derecho objetivo en el caso concreto con desinterés objetivo para resolver un conflicto. De hecho, de haberse atribuido esta actividad al jefe de la oficina judi-

${ }^{53}$ El texto literal que pretendía introducir el Anteproyecto era el siguiente: «4.- Si el Secretario judicial, tratándose de una reclamación de deuda fundada en un contrato entre un profesional y un consumidor, apreciase el posible carácter abusivo de cualquier cláusula que constituya el fundamento de la petición o que hubiese determinado la cantidad exigible, dará cuenta al Tribunal quien, en su caso, oirá a las partes por cinco días, resolviendo lo procedente mediante auto dentro de los cinco siguientes. Para dicho trámite no será preceptiva la intervención ni de Abogado ni de Procurador. De estimar el carácter abusivo de alguna de las cláusulas contractuales, el auto se que dicte, que será directamente apelable, determinará las consecuencias de tal consideración acordando, bien la improcedencia de la pretensión, bien la continuación del procedimiento sin aplicación de las consideradas abusivas.» Y el informe del Pleno del Consejo General del Poder Judicial, de 11 de julio de 2013, en sus puntos 47 y 48, señaló literalmente que: "el Anteproyecto viene a atribuir esa obligación al Secretario judicial y no al Juez, articulando un procedimiento para decidir sobre el carácter abusivo o no de la cláusula que solo se iniciará si el Secretario judicial entiende que algunas de las cláusulas pueden tener tal carácter. Lo que es distinto a lo que dice la STJUE, que insistimos, indica que es el Juez quien, de oficio y en todo caso, sin necesidad de oposición del demandado ni a instancia de otra persona, ha de examinar las cláusulas de un contrato suscrito entre un profesional y un consumidor a fin de valorar la existencia o no de posibles cláusulas abusivas. Se considera, en consecuencia, que la nueva regulación es una clara invasión de la función jurisdiccional y no cumple los términos de la sentencia del TJUE». 
cial, como denunció en su momento el Consejo General del Poder Judicial, nos encontraríamos ante una "clara invasión de la función jurisdiccional».

En fin, cualquier solución que por último se adopte en el ejercicio de la libertad de configuración legislativa ha de pasar por atribuir al «juez», y en modo alguno al "Secretario Judicial», el control de «abusividad ${ }^{54}$, con independencia de que el procedimiento esté debida o más bien indebidamente atribuida o no en exclusividad, sin delegación ni colaboración, al funcionario jefe de la oficina judicial que es el «Secretario Judicial». Por ello, junto a la solución que apunta la abogada general, sin duda respetuosa con uno de los marcos legislativos que nos vinculan, concurren otras posibilidades que no solo garanticen el control de las cláusulas abusivas, sino que además sean acordes con el respeto al principio constitucional de exclusividad en el ejercicio de la potestad jurisdiccional. Veamos algunas de las principales:

\section{A) La vuelta a la situación anterior a la Ley 13/2009}

Volver a la situación anterior a la Ley 13/2009, esto es, atribuir este procedimiento al titular de la potestad jurisdiccional, permitiría al «juez» controlar las cláusulas abusivas solo introduciendo una previsión al respecto, sin plantear dudas de constitucionalidad.

Esto no tendría que excluir el mantenimiento de las mejoras introducidas por la Ley 42/2015. Recordemos que, entre otras cosas, aportó coherencia en materia de legitimación y sirvió para resolver ciertas

${ }^{54}$ Esta palabra no se encuentra en el diccionario de la Real Academia Española en la actualidad. Pero su uso se encuentra suficientemente extendido en la literatura jurídica. Así, por ejemplo, De Lucchi LóPEZ-TAPIA, Y., «Los efectos de la declaración de abusividad de cláusulas hipotecarias en la ejecución", en Vivienda, préstamo y ejecución (coor.: ESPEJO y MURGA, FERNÁNDEZ y TOMÁs), Thomson Reuters Aranzadi, Cizur Menor, 2016, págs. 795-812. Y lo mismo cabe decirse de la jurisprudencia. Así, entre otras muchas, la STS, Sala 1. ${ }^{a}$, Secc. 1. ${ }^{a}$, núm. 567/2016, de 27 de septiembre (Ponente: Sr. Salas Carceller), alude a "la declaración de abusividad de las cláusulas»; el ATSJ Navarra, Sala de lo Civil y Penal, Secc. 1. a , núm. 9/2016, de 26 de septiembre (Ponente: Sr. Fernández URZAINouI), habla de que «parten del presupuesto de la abusividad de la cláusula contractual»; la SAP Barcelona, Secc. 15, núm. 226/2016, de 17 de octubre (Ponente: Sr. DíAz MuYor), habla del «artículo 4.2 de la Directiva 93/13, que admite el control de abusividad de una cláusula»; y la SJPI de Talavera de la Reina 4, núm. 135/2016, de 26 de septiembre (Sr. ORTIZ AGUIRRE), se refiere al «sistema de Derecho comunitario tiene el control de abusividad de las cláusulas no negociadas». En fin, el uso del término está tan extendido entre la doctrina y la jurisprudencia que, antes o después, deberá ser admitido por la Real Académica Española como un término que forma parte de la lengua castellana. 
polémicas como dejar claro que la cuenta del procurador no es impugnable por excesiva. Mejoras a las que solamente faltaría añadir en la futura reforma, que el control de admisión no solamente procede cuando reclame el procurador, tal y como establece el artículo 34.2 LEC, sino que del mismo modo deberá procederse cuando reclama el abogado, para lo que deberá incluirse en el artículo 35 LEC una previsión expresa sobre el particular, o al menos la correspondiente remisión al precepto precedente.

La determinación de imponer la prestación de pagar al abogado y procurador, en su caso, tras decidir sobre su cuantificación, puede considerarse por el juzgador como una cuestión menor y accesoria, cuando no engorrosa, a pesar de ser ocasionalmente sencilla y casi mecánica. Pero, en cualquier caso, el apoderamiento del juez, y con ello, la recuperación de la categoría de proceso que merece la reclamación de créditos generados en el proceso por abogado y procurador frente a sus clientes, se presenta urgente pues permitiría respetar no solo el derecho de la Unión sino también el marco constitucional.

Además, esta solución no representaría ninguna curiosa excepcionalidad. Recordemos que en su momento no llegó a desapoderarse al juez en otros procesos en los que también se instrumenta la técnica monitoria. Es el caso del juicio cambiario regulado en los artículos 819 a 827 LEC, que, quizá por la especialidad material del derecho cambiario y por la complejidad procedimental en la que se adopta una medida cautelar junto al requerimiento, quedó exento de invasión por el «Secretario Judicial» en la tan repetida Ley 13/2009.

B) Mantenimiento de la intervención del «Letrado de la Administración de Justicia» de modo similar a lo previsto en el artículo 815.4 LEC

También respetuosa, además de sistemática, podría ser la equiparación de la estructura competencial del procedimiento que nos ocupa a la prevista en el monitorio de los artículos 812 a 818 LEC. Esto implicaría que quedara en manos del «Secretario Judicial» la «gestión» del procedimiento, pero en colaboración con un titular de potestad jurisdiccional que ejerce discretamente control y supervisión como ya hemos visto.

Partiendo de la dación de cuenta al juez para apreciar el posible carácter abusivo de la cláusula según el modelo del artículo 815.4 LEC, en la hipótesis improbable que el documento no constituyera un 
principio de prueba del derecho del peticionario (por ejemplo, al no ofrecerse la manifestación formal), el Letrado-Secretario «dará cuenta al juez para que resuelva lo que corresponda sobre la admisión a trámite de la petición inicial» (de modo similar a lo previsto en el artículo 815.1 LEC). Y además, aunque no sea imprescindible para el derecho de la Unión pero sí para el respeto de la configuración constitucional, la oposición debería ser decidida judicialmente, con efecto de cosa juzgada o no, en el procedimiento especial para tal fin como el se regula, incluidas las correspondientes remisiones a las normas sobre tasación de costas, en los artículos 34 y 35 LEC, en una versión adaptada de lo previsto en el artículo 818 LEC.

C) Derogación del procedimiento, introduciendo, en su caso, especialidades

Solución semejante a la anterior sería derogar el procedimiento de los artículos 34 y 35 LEC y, si se considera necesario, introducir especialidades en la regulación general de los artículos 812 a 818 LEC.

Esta solución sería, en la práctica, la misma que la anterior pero alcanzada a través de otra estrategia sistemática. Así, en lugar de llevar la estructura el procedimiento monitorio a la regulación específica de los repetidos artículos 34 y 35 LEC, se trataría de lo contrario, de llevar las especialidades que se consideran necesarias a la regulación general del monitorio.

Para la reclamación de gastos de comunidad, el legislador se limitó a mantener especialidades en el artículo 21 de la Ley de Propiedad Horizontal, remitiéndose para lo demás a la regulación general de los artículo 812 a 818 LEC. Pero esta no ha sido la técnica en otros supuestos similares: en la reclamación del crédito cambiario en los artículos 819 a 829 LEC; en el monitorio previsto en el art. 101 de la Ley 36/2011, de 10 de octubre, reguladora de la jurisdicción social; en el monitorio notarial, denominado «reclamación de deudas no contradichas» de los artículos 70 y 71 de la Ley del Notariado; ni, desde luego y como no podía ser de otro modo, en el monitorio regulado en el Reglamento (CE) núm. 1896/2006, de 12 de diciembre.

Lo bien cierto es que, para cumplir los fines de adecuación a la Unión y respeto constitucional, perfectamente el legislador podría derogar los artículos 34 y 35 LEC. Y, si se considera conveniente, como parece, podría mantener las correspondientes especialidades, 
sea en los mismos preceptos o sea llevándolas al articulado de los artículos 812 a 818 LEC. Entre ellas, se encontraría ${ }^{55}$ : la norma de competencia funcional al «Secretario Judicial» del lugar en que «el asunto radicare»; la concreción del documento que contiene el crédito (minuta o cuenta detalladas); la necesidad de manifestar (formalmente) que el crédito reclamado es debido y no ha sido satisfecho; la extensión de la legitimación -y la posibilidad de «beneficiarse» de las especialidades- a favor de los herederos del abogado y procurador; la reducción del plazo otorgado a la mitad, a diez días; la adecuación por la materia a un procedimiento especial para sustanciar la oposición con independencia de la cuantía, tal y como se prevé en la actualidad en los artículos 34.2. II LEC y 35.2. II y III LEC, si bien resolviéndose de forma motivada mediante la correspondiente resolución judicial.

\section{Las posibilidades probatorias en el control de las cláusulas abusivas y los procesos sumarios}

Relacionada íntimamente con el alcance de la reforma que se avecina, se encuentra una cuestión tan relevante como la de las posibilidades probatorias en el control de las cláusulas abusivas en los procesos que, como el que nos ocupa, son sumarios.

La abogada general parece ventilar esta cuestión de una forma sencilla y casi apresurada. Viene a concluir afirmando que «la Directiva 93/13 no se opone a una normativa nacional como la controvertida en el procedimiento principal». Pero, eso sí, «a condición de que dicha normativa admita una práctica de prueba suficiente como para permitir la comprobación efectiva de si existen cláusulas abusivas, extremo que corresponde comprobar al tribunal nacional».

Las consideraciones que ofrece al respeto se limitan a señalar que según la LEC, en el examen de lo reclamado por honorarios ${ }^{56}$, se recabarán elementos que «por regla general» en las facultades de investigación «deberían bastar para que se pueda analizar y apreciar si existen cláusulas abusivas». Solamente en el caso de que el contrato de pres-

${ }^{55}$ No sería necesario incluir la excepción al carácter preceptivo de la postulación, pues ya se contempla como regla general para el monitorio en los artículos 23.2.1. ${ }^{\circ}$, 31.2.1. ${ }^{\circ}$ y 814.2 LEC.

${ }^{56}$ La abogada general las concretas en las siguientes: «no sólo los autos del procedimiento judicial que es origen de la reclamación sino también la minuta del abogado y otros documentos, tales como el presupuesto o el propio contrato. Además, cuando los honorarios se impugnen por excesivos, los secretarios judiciales deberán oír a los abogados y, si éstos no aceptan la reducción de sus honorarios, pasar testimonio de los autos al colegio de abogados para que emita informe». 
tación de servicios fuera oral -como, por cierto, suele ser lo habitual«podría ser imprescindible contar con la posibilidad de que se practicaran otro tipo de pruebas, como la testifical, para poder examinar la existencia o no de cláusulas abusivas». Cosa que, según afirma, no se vería impedida en cuanto «las disposiciones de la LEC podrían interpretarse de conformidad con el Derecho de la Unión en la medida en que, en casos justificados, las facultades de control de los secretarios judiciales pudieran ir más allá del examen de la prueba documental, incluyendo la declaración de testigos».

El derecho de la Unión queda, pues, salvaguardado en cuanto en la práctica las limitación probatoria a los documentos permitirá el control de las cláusulas abusivas, y cuando sea insuficiente, por ser oral el contrato de prestación de servicios, sencillamente podrán ampliarse. Aunque esta consideración resulta coherente con el discurso contenido en las conclusiones de la abogada, y parezca contentar las aspiraciones de este colectivo profesional ${ }^{57}$, considerar que el hecho de que el «Secretario Judicial» pueda conocer de la cuestión, incluso ya con carácter plenario, evidencia una vez más el hecho de que el jefe de la oficina judicial está realizando una función de carácter jurisdiccional e invasora de funciones netamente judiciales ${ }^{58}$.

Junto a esto, hace emerger un problema que trasciende de los límites del procedimiento que ahora nos ocupa. Si, en definitiva, el control de oficio sobre las cláusulas abusivas en todo proceso ha de ser suficiente, lo que equivale a un conocimiento plenario, de algún modo estaría en franca descoordinación con el eventual carácter sumario, sea en los motivos de oposición como también en los medios de prueba admisibles, del proceso en el que dicho control se inserte.

${ }^{57}$ Según Esteban, P., «Los Letrados de Justicia pueden controlar las minutas abusivas de los abogados», cit., el sistema se considera perjudicado por cuanto no se les dota de facultades en este ámbito. Afirma que «en diversas ocasiones, el colectivo ha expresado quejas al nuevo sistema, puesto que si bien la ley les hace responsables de procedimientos antes reservados a los jueces y de su resolución, sin embargo no se les dota de las facultades propias de los órganos jurisdiccionales, como por ejemplo la práctica de prueba. El colectivo reivindica que es un "sistema mal definido" por la ley que tiene consecuencias para el ciudadano».

${ }^{58}$ No parece preocuparle esta cuestión a Domínguez RuIz, L., «Cláusulas abusivas y procedimiento para reclamar los honorarios de los abogados...», cit., pág. 15, cuando literalmente señala sobre la atribución a los secretarios judiciales del conocimiento plenario que "éstos contarían con medios suficientes para comprobar la existencia de dichas cláusulas. Ahora bien, en palabras de la Abogada General la comprobación de este extremo corresponde al tribunal nacional. Es decir, que si instaurado este control de oficio, el tribunal nacional entendiese que no hay posibilidades suficientes de prueba debería plantear una nueva cuestión prejudicial. Ahora bien, por tribunal nacional debe entenderse también letrado de la Administración de Justicia, teniendo en cuenta que la Abogada General los considera también "órganos jurisdiccionales»». 
No va a negarse ahora que un control de «abusividad» en tales condiciones deba impedir per se la existencia de procesos sumarios, pero, como mínimo, podría alterar sustancialmente la operatividad de una técnica de tutela judicial ya de por sí precaria como la sumaria frente a medidas cautelares que pueden obtener unos resultados si no idénticos sí bastantes similares ${ }^{59}$; y que solamente es indiscutiblemente útil para sacar papel y poder aumentar la estadística, pero que ofrece una solución transitoria e insatisfactoria al mantener subsistente el conflicto por cuanto no impide abrir un proceso plenario ulterior sobre la misma cuestión.

En fin, el legislador pronto va a tener una reforma procesal en su tejado. Cuando esto ocurra, ya veremos si estará a la altura.

${ }^{59}$ Véase CALderón CuAdrado, M. P., «Tutela anticipatoria, procesos sumarios y medidas cautelares. (Con ocasión de la sentencia del Tribunal Constitucional 210/1993 de 28 de junio)», en Diario la Ley, núm. 2, 1995, págs. 1086-97. 